\title{
A G van Aarde as teoloog (1979-)
}

\author{
E van Eck \\ Universiteit van Pretoria
}

\begin{abstract}
A G van Aarde as theologian (1979-)

This article is an attempt to give a brief overview of the different theological points of departure of Van Aarde's theological model, which has been lectured in the Department of New Testament Studies (Sec A) at the University of Pretoria since 1984 . The ways in which this theological model are advocated are traced through his lectures, and his many scientific publications are also taken into consideration. From his theological model it is clear that, for Van Aarde, there is an indissoluble relationship between epistemology, methodology and teleology. In this connection, attention is given to the different epistemological, theological and hermeneutical presuppositions of his theological model. The conclusion is made that his theological model succeeds in being relevant and committed to reality with reference to the church in today's mondial culture.
\end{abstract}

\section{KORT BIOGRAFIESE AANTEKENINGE}

Andries Gideon van Aarde is gebore op 25 April 1951 te Pretoria. Hy matrikuleer aan die Hoërskool Wonderboom, Pretoria in 1968. Hy behaal die volgende grade aan die Universiteit van Pretoria: BA (1971), BD (1974), BA (Hons) Grieks en Semitiese Tale (1977), MA in Semitiese Tale (1978) en DD in Nuwe-Testamentiese Wetenskap (1982). Gedurende 1973-1974 is hy navorsingsassistent in die Departement Nuwe-Testamentiese Wetenskap, gedurende 1979-1980 tydelik-deeltydse dosent in Grieks en gedurende 1979-1983 hulpdosent in die Departement Nuwe-Testa- 
mentiese Wetenskap, Fakulteit Teologie (Afd A) aan die Universiteit van Pretoria. Sedert 1980 doseer hy ook as permanent-voltydse senior lektor in die Departement Ou-Testamentiese Wetenskap, met opdrag Bybelkunde. Met aanvang 1984 word hy oorgeplaas na die Departement Nuwe-Testamentiese Wetenskap en bevorder tot permanent-voltydse mede-professor en tot professor en Departementshoof op 1 Junie 1989. Sedert 1986 doseer hy ook in deeltydse hoedanigheid Grieks aan die Hervormde Teologiese Opleiding, Klipdrif te Hammanskraal. Hy is vanaf 1975 predikant in die Nederduitsch Hervormde Kerk van Afrika.

Prof Van Aarde is dus vanaf 1979 betrokke in die Departement Nuwe-Testamentiese Wetenskap.

\section{AS HULPDOSENT IN DIE DEPARTEMENT NUWE-TESTAMENTIESE WETENSKAP (1979-1983)}

Gedurende hierdie tyd het Van Aarde hoofsaaklik vir homself duidelikheid gekry oor sy beskouing van die Skrif en die gesag daarvan.

In sy Skrifbeskouing meen Van Aarde (1982b:16) dat as uitgangspunt die diversiteit van die Skrif as beginsel aanvaar en erken moet word: God het mense baie boeke laat skryf, nie net één nie, en hierdie boeke noem ons die Bybel. Hierdie formulering veronderstel dus 'n Skrifbeskouing wat Bybel, Bybelskrywer en Bybelleser in relasie met God sien. Volgens Van Aarde (1982b:16) veronderstel laasgenoemde op sy beurt weer 'n bepaalde inspirasieteorie. Skrifbeskouing en inspirasie gaan dus hand aan hand.

Die bekende onderskeid in ortodoks-teologiese kringe, te wete tussen organiese- en meganiese inspirasieteorie, kan hier as voorbeeld dien. Teoloë wat probeer om die verskille in die Skrif te elimineer of harmoniseer, huldig gewoonlik 'n meganiese inspirasieteorie. Die menslike responsie van die Bybelskrywer word so totaal buite rekening gelaat.

Volgens Van Aarde (1982b:16) waarborg 'n besliste keuse vir 'n organiese inspirasieteorie, soos byvoorbeeld geneem in Nederland tydens die Algemene Sinode van Delft in 1979, nie noodwendig die teenoorgestelde resultate as hierbo genoem nie. Hoewel die meeste teoloë 'n keuse vir die organiese beskouing maak, verval die toepassing van hierdie teorie dikwels in 'n meganisties-verbale en fundamentalistiese inspirasiebeskouing. Van Aarde (1982b:16) is van mening dat dit ook die situasie in Suid-Afrika is, veral op grond van die invloede van Kuyper, Bavinck, Ridderbos en die vroeë-Berkhouwer hier op eie bodem. Juis hierom is 'n inspirasieteoretiese uitgangspunt dat die Bybel God se Woord in mensewoorde is, 'n noodsaaklike vooronderstelling vir verantwoordelike Skrifhantering. 
Hierdie vooronderstelling maak dit ook moontlik om een van die belangrikste kenmerke van die Skrif, te wete sy diversiteit en pluriformiteit in vorm en inhoud, na waarde te kan skat sonder om onnodig sensitief te wees dat die gesag van die Skrif op hierdie wyse aangetas sal word. Hierdie beklemtoning van die diversiteit en pluriformiteit van die Bybel (èn Bybelse Teologie) was volgens Van Aarde (1982b:16) die resultaat van die metodologiese tendens van die historiese kritiek. Enersyds het die Formgeschichte en die Traditionsgeschichte die aandag gevestig op die invloed wat die verskillende sosiologiese situasies (Sitze im Leben) in die vroeë kerk gehad het in die skep van die verskillende Gattungen. Andersyds het die opkoms van die Redaktiongeschichte die meeste kritiese teoloë oortuig dat verskillende teologiese tendense tussen verskillende Bybelboeke aanwysbaar is. Met hierdie resultate wil Van Aarde hom vereenselwig wanneer hy Eduard Lohse instemmend soos volg in Afrikaans weergee: '...die Nuwe Testament [en Ou Testament] [leer nie] 'n eenheid nie, maar [bied] ' $n$ verskeidenheid teologieë' (Lohse aangehaal in Van Aarde 1982b:16; sy vertaling). Saam met Ernst Käsemann is Van Aarde (1982b:16) verder van mening dat daar nie alleen tendensieuse spanninge in die Bybel aangetoon kan word nie, maar ook onversoenbare teologiese kontradiksies.

Hy stel dit egter duidelik dat hierdie oortuiging nie die gesag van die Skrif of die inspirasie van die Heilige Gees ontken nie (Van Aarde 1982b:16). Die gesag van die Skrif is nooit afhanklik van die aanwending van 'n bepaalde eksegetiese metode nie (Van Aarde [1981a]:16). Die aanvaarding van die resultate van die historiese kritiek is eerder ' $n$ oortuiging wat ten volle rekening hou met die organiese inspirasie-teorie en die toepassing van die konsekwensies daarvan. Ook word hiermee nie ontken dat sekere konsepte in baie Bybelboeke wel besonder prominent figureer nie. Wat die Ou Testament betref, kan daar byvoorbeeld verwys word na begrippe soos inter alia die 'Sionstradisie', 'Dawidstradisie', 'vergelding' en 'geregtigheid' en in die Nuwe Testament inter alia na die begrippe 'geregtigheid', 'liefde' en 'heilsgeskiedenis'.

Omdat nie een van hierdie begrippe egter in al die boeke van die Bybel voorkom nie en soms ook nie een-dimensioneel in 'n bepaalde boek nie, meen Van Aarde (1982b:16) dat die aantoon van énige 'sentrum' in die Skrif 'n futiele en onwenslike poging is. 'n Bepaalde Bybels-teologiese struktuur behoort daarom nie as 'n sleutel gebruik te word om die hele Bybel hermeneuties te beskryf en te verstaan nie.

Bogenoemde Skrifbeskouing van Van Aarde sou soos volg opgesom kan word: Die diversiteit en pluriformiteit van die Bybel moet erken word, die keuse vir 'n organiese inspirasieteorie moet konsekwent deurgevoer word, die feit dat die Bybel in die eerste plek mensewoorde is, moet ernstig opgeneem word en die Skrif moet toe- 
gelaat word om homself te verklaar en nie deur een of ander sentrale tema as hermeneutiese sleutel wat as 't ware bo-oor die Skrif 'loop' nie.

Hierdie aspekte van sy Skrifbeskouing kom veral duidelik na vore wanneer hy die Skrifbeskouinge van onder andere Karl Barth en James Barr onder die vergrootglas plaas (Van Aarde 1981b:16; 1981c:16). Die invloed van Barth (en ook Bultmann) op die vorming van sy eie dialektiese denkwyse word ook hieruit duidelik.

Syns insiens het die liberale teologie van die negentiende eeu die reformatoriese eenheid tussen wetenskap en teologie uitmekaargehaal, terwyl die ortodoksie hulle weer in die Eeu van die Verligting van die wetenskap geïsoleer het. Barth het syns insiens egter probeer om met sy dialektiese teologie die eenheid tussen teologie en wetenskap te herstel. So is die vraag na die dialektiese verhouding tussen woord van die mens' en 'Woord van God' aan die orde gestel. Barth se erkenning dat die Bybel ook 'woord van die mens' is, was volgens Van Aarde (1981b:16) 'n duidelike rugdraai op die fundamentalisme (kyk ook Van Aarde [1981a]:6). Alhoewel sommige geleerdes van mening is dat Barth se bydrae as 'liberalisties' geteken moet word in terme van 'n aanslag op die gesag van die Skrif (kyk Van Aarde [1981a]:6), meen Van Aarde dat hierdie bydrae van Barth die moontlikheid gebied het vir die eerlike kritiese navorser wat oortuig begin raak het van die feit dat dit mense is en niks anders as mense nie, wat in die Skrif aan die woord is (Van Aarde 1981b:16). Volgens Van Aarde het selfs Barth egter nie die volle konsekwensies van die dialektiek Bybel as 'Woord van God'-woord van die mens' deurgetrek nie. Daarvoor was sy verleentheid met die historiese kritiek en toevlug na 'teologiese eksegese' te duidelik 'n besliste keuse vir die 'goddelike aspek' van die Skrif ten koste van die 'menslike aspek'. Van Aarde (1981b:16) is daarom van mening dat Barth se dialektiese Woordteologie nie 'n ander konsekwensie bied as dat die gesag van die Skrif alleen op die 'goddelike' berus en dat die 'ware openbaring' alleen daar te vind is nie. Die 'menslike aspek' aan die ander kant is alleen die objek van die historiese kritiek.

Teenoor bogenoemde Skrifbeskouing van Barth meen Van Aarde (1981c:16) dat Barr se Skrifbeskouing 'n verskuiwing aantoon wat veral betref Barth se teologie van die Woord. Van Aarde stem met Barr saam dat Barth in sy Skrifbeskouing die menslike responsie onderbeklemtoon, veral omdat hy nie reg laat geskied aan die menslike totstandkoming van die Bybel as sodanig nie. Die Bybel moet nie gesien word as bloot 'n historiese dokument nie, maar as 'n menslike historiese responsie in die geloof. Die mens is die draer van die goddelike 'daad'. Op grond hiervan beteken 'inspirasie' dat God teenwoordig was toe die gelowige responsie van die volk van God in onder andere aanbidding en gebed in die Skrif neerslag gevind het, of soos Van Aarde ([1981a]:8) dit formuleer: 'Agter die ontstaan van die Bybel, is 'n 
daad van die verlossende God. Dit kan "inspirasie" genoem word.' Hierteenoor beteken 'inspirasie' nie dat allerlei ouderwetse eksegeties-hermeneutiese dwangreëls op die studie van die Bybelse teks van toepassing gemaak kan word nie (vgl Van Aarde [1981a]:8).

Wat die grense van die kanon betref, is die kanon, alhoewel de facto toe (dit wil sê, genoegsaam vir die kerugma), de iure so oop en wyd 'as die Here se genade'. Die gesag van die Skrif is nie geleë in die feit dat die Skrif onfeilbaar is nie, maar omdat dit juis in hierdie boeke is en nie in ander nie, waarin die kristallisasie van die geloofsgemeenskap van die volk van God met God, volgens die reformatoriese kerklike tradisie gefikseer geraak het. Die Skrif is dus net 'woord van die mens', die essensiële en genoegsame toegang tot die 'Woord van God' (Van Aarde 1981c:16). In sy professorale intreerede, agt jaar later, formuleer hy sy standpunt in hierdie verband soos volg:

(O)p eg reformatoriese wyse (beskou ek) die Nuwe Testament as die 'kennisbron' van die verhouding tussen God en sy skepping. Die verhouding van God met die volk Israel is intertekstueel betrek in die Nuwe-Testamentiese getuienis oor hoe God in en deur Jesus Christus die mens met Homself versoen het, en daarom is die Ou Testament deel van dié kennisbron. Natuurlik is enige buite-Bybelse teks (of artefak) wat lig op die Nuwe Testament kan werp, van wetenskaplike belang.

(Van Aarde 1989d:14)

Die basis van bogenoemde Skrifbeskouing en Skrifgebruik word deur Van Aarde (1985c:16) tipeer as dié van die dialektiese- en eksistensiële teologie, of anders gestel: Dit dui op die verskuiwing vanaf 'n meganiese/verbale inspirasieteorie na ' $n$ inspirasieteorie wat erns maak met die historiese wording, kontekstualiteit en teks-immanente poëtiek van Bybelse tekste, sowel as die relasionele dimensie tussen enersyds God en die mense en andersyds tussen kerkmense onderling en tussen die kerk en die wêreld. Die vraag kan gevra word of so 'n Skrifbeskouing nie 'n verureemding met betrekking tot die Reformasie en ook die 'Hervormde' teologie impliseer nie. Van Aarde (1985c:16) is van mening dat juis die teendeel waar is: Dit dui eerder op 'n verdieping van die Reformatoriese beginsels, asook van die 'Hervormde' teologie.

Die Bybel kan alleen kanon wees omdat dit na sy aard norm van God is. Alleen vanuit die gesigspunt van die geloof kan en word die gesag van die Bybel as Woord van God herkenbaar en erkenbaar. Hierdie gesag van die Bybel is ten nouste aan die inhoud van die Bybel gekoppel. Die Bybel is bewerker van die geloof en kan alleen deur die geloof as Woord van God erken word. Die oorsprong van die gesag van die Bybel lê eerstens in sy selfgetuienis en tweedens in die getuienis van die 
Heilige Gees wat in die harte van gelowiges hierdie gesagsoortuiging werk (kyk ook Van Aarde [1981a]:19). Die waarheid van die Bybel moet dan ook nooit met feitelike waarheid gelykgestel word nie. Dit is nie wat die Bybel wil wees nie (vgl Van Aarde 1985c:16).

Beteken bogenoemde Skrifbeskouing van Van Aarde nie dat die reformatoriese grondstellings oor die perfectio, perspiciutas en sufficientia (kyk NGB, Art 7) van die Heilige Skrif losgelaat word nie? Hy sien dit juis as die teendeel daarvan (Van Aarde 1985c:16). Die betroubaarheid (perfectio) is geleë in die heilsboodskap wat die Bybel verkondig. Hierin is die Bybel volkome onfeilbaar, omdat die heilsboodskap van die Bybel geleë is in Jesus Christus. Wat God in sy heilsboodskap bekend wil maak, is gevolglik ook volkome deursigtig (perspiciutas), maar nie só deursigtig dat 'n grondige Bybelwetenskap en teologie nie nodig is nie. Laastens is die Bybel ook genoegsaam (sufficientia), nie in sy aantal boeke nie, maar wel in sy heilsbedoeling.

Impliseer bogenoemde verstaan van die betroubaarheid, deursigtigheid en genoegsaamheid van die Skrif dat die bestaansreg van die vak Bybelse Teologie so ontken word? Inteendeel, teoloë wat na 'n 'harmonieuse Bybel' streef op grond van die reformatoriese spreuk tota Scriptura doen somtyds 'n ander reformatoriese spreuk, te wete sola Scriptura, geweld aan (kyk Van Aarde 1982c:16). Want sodra 'n sisteem begin funksioneer as hermeneutiese sleutel, word dit 'n uitleginstansie bó die Bybel, en word die outosemantiese aspek van die Bybel, oftewel die sola Scriptura-beginsel tweede geplaas.

Volgens Van Aarde (1982c:16) kan die twee tota Scriptura-benaderings van die 'openbaringshistoriese-skema' en die 'kanon-benadering' hier as voorbeelde dien. Eersgenoemde skema gaan van die vooronderstelling uit dat dit God behaag het om Hom en sy wil in die loop van die geskiedenis al hoe duideliker te openbaar. 'n Bepaalde verband en volgorde bestaan dus tussen sake en gebeurtenisse in die Bybel, wat dui op 'n 'gewyde geskiedenis'. 'n 'Diepere geestelike' betekenis is so in die Bybel teenwoordig. Bybels-teologies impliseer hierdie standpunt dat 'n latere uitspraak in die Bybel altyd hermeneuties deurslaggewend teenoor die voorafgaande is' (Van Aarde 1982c:16). God se openbaring het dus kronologies plaasgevind in terme van sowel die verskillende insidente in elke boek as in die volgorde van boeke in die Bybel. Sommige eksponente gebruik in hierdie verband, wat die Ou Testament betref, die volgorde van boeke in die Afrikaanse Bybelvertaling en ander weer die volgorde van die boeke in die Joodse kanon.

Die swakheid van hierdie skema is so opsigtelik dat dit selfevaluerend is (Van Aarde 1982c:16). Die feit dat sekere boeke in die Bybel ontstaan het ver verwyderd van die gebeure waarna dit verwys (bv die Evangelies), dat sommige boeke nie van voor tot agter kant en klaar geskryf is nie en dat die verskillende boeke in die Bybel 
nie gelyktydig as kanon aanvaar is nie, word nie in hierdie skema verantwoordelik verdiskonteer nie. So 'n Bybelse teologie is naïef en respekteer nie die eie-aard van die Skrif nie.

Dieselfde kan ook van die sogenaamde kanon-benadering van byvoorbeeld B S Childs gesê word. Hierdie benadering pretendeer onder andere dat dit erns maak met die eindfase van die wordingsgeskiedenis van die Bybelse tekste. So 'n benadering is volgens Van Aarde (1982c:16) 'n winspunt vir enige Bybelse teologie. Childs se verstaan van die eindfase van die wordingsgeskiedenis van die Bybelse tekste kom egter daarop neer dat 'n literêre korpus, soos byvoorbeeld die Evangelies as produk van 'n kanoniserende proses, as hermeneutiese konteks moet funksioneer. En dit kan tog nie.

Volgens Van Aarde (1982c:16) moet ons eerder eerlik erken dat, wat betref die metodologiese kriteria waarvolgens Bybelse teologie beoefen behoort te word, ons tans nog in die duister is. Die Bybelse teologie verkeer beslis in 'n metodekrisis.

Die soeke na antwoorde op hierdie vraag en nog baie ander, meen Van Aarde (1982c:16), vereis werfskoonmaak en voorlopige standpuntinname. Ooglopende swak wetenskaplike benaderinge moet uitgewys word, maar ook moet die oog gevoelig bly vir vrese dat sommige benaderinge wat erns maak met die diversiteit van die Bybel, nie die gesag van die Bybel moontlik kan aantas nie. Vier sake behoort altyd in gedagte gehou te word:

* Bybelse teologie behoort rekening te hou met die verskillende teologieë in die Bybel;

* die 'finale teks' (nie die kanon nie!) behoort die hermeneutiese konteks van hierdie teologieë te wees;

* die beskrywing van hierdie teologieë moet nie geskied aan die hand van selektiewe temas nie;

* historiese en literêre beskrywing moet opgaan in literêr-hermeneutiese en teologies-hermeneutiese kommunikasie.

Daar sal hier onder aangetoon word dat hierdie dan ook as die 'program' beskou kan word waarvolgens die opleiding in die era vanaf 1984 in die Departement Nuwe-Testamentiese Wetenskap aan die Fakulteit Teologie (Afd A) gestruktureer en gedoseer is. 


\section{AS PROFESSOR IN DIE DEPARTEMENT NUWE-TESTAMENTIESE WETENSKAP SEDERT 1984}

\subsection{Epistemologie}

Van Aarde gaan in sy beoefening van die wetenskap (en dus teologie) uit van die standpunt dat daar ' $n$ onlosmaaklike verband bestaan tussen epistemologie, metodologie en teleologie. Hierdie uitgangspunt kom onder andere neer op die beginsel dat die epistemiese status wat aan objekte toegeken word, bepaal word deur gedeelde sosiologiese waardes van wetenskaplikes (vgl Kuhn 1970). Die epistemiese status

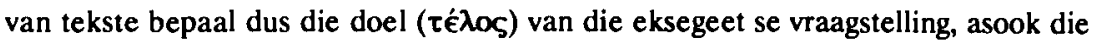
aard van sy metode. Waarheid hou dus ook verband met die doel waarom 'n bepaalde vraag gevra word, dit wil se dit is relatief ten opsigte van die doel van die vraagstelling (Van Aarde 1991b:3).

Volgens Martin (1987:370-385) kan daar in die verlede en hede, drie kenteoretiese paradigmas aangetoon word, te wete dié van die vitalisme, meganisme en holisme. Kenmerke van die vitalisme is simboliek (in terme van tipologie/allegorie en bv die bekende viervoudige Skrifuitleg), terwyl die meganisme se kenmerke uitgedruk kan word in terme van dualisme, eksakthede, genetiese-kousaliteit en atomisme. Die historiese kritiek (bv die Formgeschichte) het volgens Martin (1987:381) sy ontstaan as gevolg van die opkoms van hierdie kenteoretiese paradigma gehad. Volgens Martin het die wetenskap egter reeds afskeid van hierdie paradigma geneem en verkeer tans wat wetenskapsbeoefening betref, in 'n volgende paradigmatiese fase, te wete dié van die holisme. As nuwe kenteorie veronderstel holisme dat die Cartesiaans-Newtoniaanse denkmodel van die moderne era nou agtergelaat word. Wetenskaplikes in sowel die natuur- en geesteswetenskappe deel tans nuwe sosiologiese, antropologiese en psigologiese waardes wat die gevolg het dat nuwe doelwitte geformuleer word. Dit verklaar ook die nuwe vraagstellings en metodes wat tans op die wetenskaplike terrein, insluitende die teologiese dissiplines, ontwerp word (Van Aarde 1990d:294; vgl ook Van Aarde 1991b:1).

Die holistiese denkmodel bou verder op die insigte van onder andere die kwantumfisika, waar 'n saak op grond van die onsekerheidsbeginsel twee sake gelyktydig kan wees (kyk Van der Merwe 1989:483 n a v Van Arkel 1988:226). In holisme vervang 'sintetiese oordele' die 'analitiese oordele' van die meganistiese paradigma in dié opsig dat daar na groter gehele eerder as die 'waarheid' in die fundamentele kerndeel gesoek word. 'Nou word daar geoordeel dat die grootste geheel die organisme vorm en die dele daarvan hoogstens organe kan wees' (Van der Merwe 1989: 449-450). In holisme word grense en identiteite dus makliker uitgewis en immanensie en transendensie kan deurmekaar vloei (Capra 1989:75-89). Teologie, sosiologie, antropologie, psigologie en ideologie kan daarom as uitwisselbare terme ge- 
bruik word (kyk Van Aarde 1988a:58-59; Van der Merwe 1989:500). Dit lyk asof relativisme en pluraliteit die 'nuwe tyd' kenmerk (Van Aarde 1990d:297; 1991b:4). Van Aarde haal Brauer (1984:11-17) instemmend aan wat drie redes aanvoer hoekom hierdie nuwe paradigma tot stand gekom het: pluralisme in die samelewing en die Christendom, dialoog tussen die verskillende godsdienste van die wêreld en sekularisasie.

In Suid-Afrika is dit veral Willem Vorster (1987:374-394), die mede-promotor van Van Aarde se proefskrif, wat van mening is dat die wetenskap, wat sy benaderinge tot eksegetiese metodologie betref, in ' $n$ proses van beweging is na ' $n$ postkritiese, holistiese paradigma. Volgens Vorster is die opkoms van moderne literêr-kritiese teksteorieë soos die narratologiese, ideologiese, psigologiese en dekonstruktiewe lees van tekste hiervan ' $n$ aanduiding. Veral die verskuiwing van die historieskritiese lees van tekste na 'n sosio-historiese lees van die teks dui op hierdie paradigmatiese verskuiwing. Van Aarde (1988a:49-64; 1990d:293-311; 1991b:1-16; 1991b:1-15; 1991c: 1-9) kan egter nie hiermee saamstem nie. Hierdie standpunt formuleer hy soos volg: Die term 'paradigma' en die naam Thomas Kuhn gaan vir ons doeleindes saam. Laasgenoemde verstaan onder die term 'paradigma' 'n konsepsuele verwysingsraamwerk wat gedeel word deur ' $n$ geleerde gemeenskap wat hulle in staat stel om modelprobleme te identifiseer en modeloplossings daarvoor te vind (kyk Kuhn 1970:182). Fritjof Capra (1982:33-36) gebruik die term 'paradigma' egter in ' $n$ wyer verband. Vir hom dui dit op die totaliteit van denke, persepsies en waardes wat lei tot 'n spesifieke visie op die werklikheid, 'n visie wat die grondslag vorm van die wyse waarop ' $n$ bepaalde sosiologiese gemeenskap homself organiseer. Kwantumfisika het syns insiens 'n nuwe konsepsuele verwysingsraamwerk laat ontstaan en dit noem hy 'n 'multi-disciplinary, holistic approach to reality' (Capra 1982:89). Op grond hiervan meen Van Aarde (1991b:9) dat Capra 'n beter definisie gee van wat 'n paradigma is as Kuhn. Capra se definisie moet egter nie as botsend met dié van Kuhn gesien word nie, maar eerder as meer verduidelikend (Van Aarde 1991b:9).

Wanneer Van Aarde in debat met Vorster gaan, waar laasgenoemde meen dat ons vandag met 'n nuwe paradigma werk omdat ons nie meer die historiese-kritiek presies soos voorheen gebruik nie, maak hy veral gebruik van Capra se definisie van wat 'n paradigma is. Die verduideliking wat Capra op Kuhn se definisie gegee het, kom daarop neer dat 'paradigma' te make het met die visie op die werklikheid. Dit is dus meer as net gedeelde waardes, gemeenskaplike probleme, gemeenskaplike modelle en gemeenskaplike metodes om gemeenskaplike probleme te hanteer. Daarom sal enige afwyking van ' $n$ visie op die werklikheid, wat vir die moderne 
mens ' $n$ metafisiese visie is, 'n verandering van paradigma beteken (Van Aarde 1991b:9).

As voorbeeld dien die wyse waarop ' $n$ teks bestudeer word. Daar is tussen die wetenskaplike as subjek en die objek ( $\mathrm{d}$ w s die teks) 'n afstand, maar ook 'n bepaalde verhouding. Die verhouding van die subjek (die wetenskaplike) tot die objek (die teks) word bepaal deur die subjek se totale waarneming van die werklikheid. Indien die houding/waarneming van die wetenskaplike tot die werklikheid van so 'n aard is dat hy meen dat die werklikheid 'plat' is, sal hy van mening wees dat die werklikheid volledig waarneembaar en kenbaar is en dus ook enige teks. Na Galileï en Newton het die besef egter ingetree dat die werklikheid nie 'plat' is nie. Hierdie verandering van die visie op die werklikheid bring mee dat die wetenskaplike nie anders kan as om - anders as Plato vroeër - nie meer te dink in eksakte terme van subjek en objek nie, maar te besef dat daar 'n 'onsekere relatiwiteit' tussen subjek en objek bestaan. Die wetenskaplike dra dus self relatief by tot die kennis van die objek.

In 'n organismiese holisme, wat Capra bepleit, lê die kennis nie meer in die 'ander ding', in die 'beheer', die verkenning van die objek nie, maar in die vind van die subjek binne-in die netwerk van die 'intertekstuele' betrekkinge waaruit die objek bestaan. Indien die organismiese holisme as 'n ideologiese konsep sou kan konkretiseer, sal dit volgens Van Aarde (1990d:300) dus wel kon neerkom op 'n paradigmaverandering in die Kuhniaanse sin van die woord. In die organismiese holisme kan hy egter nie sien 'how this [ $\mathrm{d} w \mathrm{~s}$ die holisme - E v E] constitutes a break away from the Kantian binary fission of part-and-whole' (Van Aarde 1988a:58) nie. Wat wel ingetree het sedert Immanuel Kant en nog nie verander het nie, is 'n andersoortige relasie tussen subjek en objek, te wete 'n dialektiese. Die hedendaagse verandering in terme van die vroeëre dualisme en die latere dialektiek het egter niks wesenlik verander in terme van die verhouding subjek teenoor objek nie. Dit is bloot stylsveranderinge, idiomatiese veranderinge van hierdie verhouding, maar nie 'n werklike verandering van die subjek se verhouding tot die werklikheid nie (Van Aarde 1991b:9-10). Omdat holisme as ideologie egter nog nie in 'n nuwe wetenskapsmodel gekonkretiseer het nie, kan dit nie as 'n nuwe paradigma gesien word nie. Wanneer iemand soos Vorster dus beweer dat die oorgang van die historiese kritiek na onder andere 'n sosiologiese analise van die Bybel 'n verandering van paradigma impliseer, is hy verkeerd, juis omdat dit nie 'n veranderde visie op die werklikheid is nie: 'Thus, in Kuhnian terms, I do not regard the current shifts in exegetic methodology as an indication of a process of a paradigm-switch away from the two-term part-whole to a holistic world-view' (Van Aarde 1988a:59). Selfs Generaal J C Smuts (1987:86), een van die vroeë voorstanders van die holisme (alhoewel in 'n 
ander sin as Capra) het holisme in terme van die 'dialectical two-term part-whole' gedefinieer (Van Aarde 1988a:59).

Wat Capra en ander as 'n holistiese neiging (en paradigmaverandering) in die geesteswetenskappe sien, kan volgens Van Aarde (1990d:305) eerder beskou word as 'n toenemende bewussyn van 'n plurale en ingewikkelde wêreld en werklikheid. Die 'nuwe mondiale kultuur' kenmerk hierdie wêreld. Dit is 'n wêreld waarin die wêreld se probleme almal se probleme geword het. Ons kan derhalwe praat van 'n 'globalisasie' van kultuur. Die wedersydse ontmoeting van die Eerste, Tweede en Derde Wêreld, asook die sinkretisering van Oosterse en Westerse kulture en godsdienste is deel hiervan. Dit is ook die tyd van die opkoms van bevrydingsbewegings en kontekstuele teologieë. In kort, dit is 'n tyd wat gekenmerk word deur pluraliteit ten opsigte van ervaring, interpretasie en praxis, of soos Van Aarde dit elders formuleer: 'It [ $\mathrm{d} w \mathrm{~s}$ die holisme - E $\vee \mathrm{E}$ ] is, however, not so much a switch from the Cartesian-Newtonian-Kantian way of thought to a holistic paradigm, but should rather be seen as new ways of considering how the realities of the mondial culture are taken into account in science' (Van Aarde 1988a:53).

'n Verdere probleem wat Van Aarde met die organismiese holisme en in die besonder die beginsel van relativisme in terme daarvan het, is dat dit wat die godsdiens betref, lei tot panteïsme (kyk Van Aarde 1988a:58; 1990d:308). Hy formuleer dit soos volg:

When one views the cosmos as something which does not comprise of parts in relationship to wholes, it is logical that no difference, be it dialectic or dualistic, would be made between the physical cosmos and the transcendental kingdom of God. Indeed, such an approach amounts to pantheism. Pantheism excludes faith commitment in the 'Wholly Other'. Theology would become psychology, sociology, anthropology, ideology et cetera. Theologically speaking, such a paradigm-switch or a process heading towards it, cannot be seen as progress, only as suicide.

(Van Aarde 1988a:58-69; my kursivering)

Relativisme impliseer dus nie alleen dat alle waarheid ewe goed of sleg kan wees nie, maar dat daar geen verskil tussen byvoorbeeld die waarheidsbeskouing van die Christendom en dié van die Islam is nie. Die verdere implikasies van relativisme is dat dit eerder agteruitgang in die teologie as vooruitgang sal bewerkstellig. Daarom meen Van Aarde moet die pluraliteit van ons mondiale kultuur eerder erken word (wat die holisme inderdaad doen) en so die moontlikheid open vir toleransie met betrekking tot verskillende oortuigings (Van Aarde 1988a:50-51). Toleransie maak dit moontlik om in te sien dat moderne literêre teorieë, sosiologiese-, ideologiese-, 
psigologiese- en ander pragmatiese benaderinge in die moderne eksegetiese metodologie resultate kan lewer wat bruikbaar is. Maar dit geld ook wat die historiese kritiek betref.

Verder is dit volgens Van Aarde duidelik dat die organismiese holisme as 'n postmodernistiese verskynsel monisties van aard is, ook wat die godsdiens betref. Juis op grond van die gemelde panteïstiese perspektief is daar ruimte vir 'n goddelike dimensie. Hier is egter ' $n$ ander 'metafisika' aan die werk - 'n werklikheid agter en langs die fisiese word in die fisiese self erken en gesoek. So word aan die fisiese werklikheid 'n dieptedimensie toegeken wat op vergoddeliking neerkom. Ironies kan 'n mens so 'n voorstelling alleen begryp indien hy kenteoreties steeds in terme van 'n subjek-objek verhouding dink - weer eens ' $n$ aanduiding daarvan dat die holisme se visie op die werklikheid nie verskil van die meganistiese paradigma nie. Die holisme, as postmoderne filosofiese ideologie kan dus nie werklik van die Moderne loskom nie. Volgens Kirsten (1988:31) veronderstel die holisme as postmoderne filosofie daarom 'n 'breuk met die Moderne waarvan dit egter afhanklik bly'. Dit is slegs ' $n$ 'selektiewe afskeid van die Moderne: die afskeid het nie betrekking op die moderne maatskappy nie, maar alleen op die kulturele selfbegrip van die Moderne' (Kirsten 1988:31).

Volgens Van Aarde (1990d:301) kan 'n wetenskaplike daarom nie daarop aanspraak maak om sogenaamd 'postmodern' te wees deur te beweer dat hy 'holisties' dink, maar in der waarheid steeds in die terme van dele tot 'n geheel, ofte wel in terme van of 'n Cartesiaans-dualistiese of 'n Kantiaans-dialektiese subjek-objek-verhouding redeneer nie.

Van Aarde meen dus dat ons tans hoogstens besig is met 'n beweging in die wetenskap waar ons al hoe meer raaksien dat die objek geëksploiteer word en dat 'n ekonomie van skaarste ontstaan het. Postmoderniteit verteenwoordig 'n oortuiging wat die objek in beskerming wil neem. Die kennende gees van die mens en sy tegniese vermoë om te beheer stel hom byvoorbeeld in staat om die aarde vir sy minerale te ontgin, maar so maak die mens ook die aarde arm - kennis word 'n sosiologiese mag waarmee iemand in 'n bestuurshoedanigheid, byvoorbeeld as werkgewer met kennis, 'n werknemer kan manipuleer. Die reg van die arbeider word ook al hoe meer raakgesien. ' $n$ Besef is dus besig om in te tree dat ons moderne wetenskap (modernisme) gelei het tot manipulasie en eksploitasie. Die huidige Postmoderne Era waarin die mens hom bevind, is dus 'n posisie waar hy die ellendige gevolge van die Moderne Tyd en sy tegniek begin raaksien. Postmoderniteit is en bly egter alleen op die huidige oomblik moontlik omdat dit afskeid geneem het van dit wat hy wil behou. Die Derde Wêreld is byvoorbeeld van mening dat die Eerste Wêreld dehumaniserend te werk gegaan het (met bv sy fabrieke), maar tog kan die 
Derde Wêreld nie afskeid neem van die Eerste Wêreld se ekonomiese stelsel nie. Die Derde Wêreld wil dus afskeid neem van die produkte van die Eerste Wêreld sonder dat hulle die Eerste Wêreld kan loslaat. Wat ons dus tans het, is 'n pluraliteit van ervaringe wat tipies van ons mondiale kultuur is. lets nuuts is vandag wel te bespeur, naamlik 'n insig in die gekompliseerdheid van die wêreld. Van Aarde (1991b:11) meen daarom dat ons hoogstens op pad is na 'n nuwe paradigma, maar dat ons ons beslis nie in 'n nuwe paradigma bevind nie.

Wat sou volgens Van Aarde die taak van die teologie in die hedendaagse mondiale kultuur wees? Hy formuleer dit soos volg:

Om kerk vandag te wees, bewustelik binne die reformatoriese tradisie te bly, en besonderlik in lyn met die dialektiese teologie te wees en boonop relevant te wees, eis 'n nuwe model van teologiebeoefening. In hierdie model wil ons die gansanderheid van God in ag neem, asook die eie-aard van die Christelike geloof, die postmoderne mondiale kultuur (met sy pluraliteit van ervaringe, interpretasie en praxis), en die eis om nie net op die kognitiewe te bou nie, maar ook op die emotiewe en die pragmatiese. Dit raak die idioom in die prediking, lied en gebed. Vanselfsprekend geld dit die hele kerklike lewe.

(Van Aarde 1991c:1-2)

Uit bogenoemde aanhaling is dit duidelik dat Van Aarde met iemand soos T Peters (1987:298) saamstem dat, wetenskapsteoreties gesproke, die eis om relevansie, werklikheidsbetrokkenheid en gemeenskapsdiens in die teologie in ons mondiale kultuur so relevant geword het dat dit selfs as 'n kriterium naas ander kan dien waaraan die wetenskaplikheid van die teologie vandag gemeet word. Die betrokkenheid van die teologie by die gemeenskap en die werklikheid beteken egter nie dat die teoloog se aktiwiteite absoluut moet opgaan in die sosio- en eko-politiek nie (vgl bv die hedendaagse kontekstuele teologie, of in Engels die bekende doing theo$\log y$ ). Die gevolg hiervan is die moontlikheid dat die teologie in hierdie proses van byvoorbeeld direkte politieke betrokkenheid sy eiesoortigheid en selfstandigheid kan verloor. Dit is dan ook in hierdie verband dat Van Aarde van mening is dat die predikant nooit 'politieke leier, maatskaplike direkteur of volksleier' behoort te wees nie (kyk Van Aarde 1990b:9, 14; 1990c:9, 14). Syns insiens is die gevolg hiervan in die kerk van vandag sigbaar in die opsig dat die kerk 'n onsekerheids- en identiteitskrisis beleef, want wie is nou reg, en aan wie se kant is God dan? (Van Aarde 1989d:12). Twee verdere probleme in hierdie verband is eerstens dat baie teoloë df soms sterk by die politiek betrokke raak terwyl hulle totaal onbetrokke by die gemeentelike werk van die kerk is, of hulle gemeentelike posisies gebruik ter bevordering van sekere politieke doelwitte. Tweedens bestaan daar ook vandag die 
redelik algemene standpunt dat God buite die geloofsgemeenskap en preekervaring om in die natuur ontmoet kan word.

Volgens Van Aarde (1989d:13) moét die teologie egter relevant wees, ook op die gebied van die sosio- en eko-politiek. Daar is geen twyfel dat die teologie veral vandag werklikheidsbetrokkenheid vereis nie. Daar is syns insiens egter'n belangrike kenteoretiese vraag wat teoloë vooraf eers moet beantwoord en dit is: Hoe kenbaar is die metafisiese werklikheid en op watter wyse is dit wat teologies kenbaar en denkbaar (vgl Oberholzer 1989:438-439) is, op die fisiese werklikheid van toepassing? (Van Aarde 1989d:13).

Wetenskaplike kennis het ongetwyfeld met die rede en met ervaring te doen. So het Kant (en Schleiermacher; kyk Van Aarde 1990d:304; 1991b:11) 'n 'rasionele kosmologie' by sy voorgangers geleer. Hiervolgens is God die hoogste wese wat alle werklikheid ruimtelik en tydelik begrens en as deel van die metafisiese werklikheid in sigself geken kan word. Kant het hierteenoor 'n posisie ingeneem wat nog empiries nog rasionalisties was, maar wat basiese elemente van beide ingesluit het (vgl Hopper 1987:46). Kant het oortuigend geredeneer dat die mens (as subjek) die werklikheid (as objek) nie ken soos dit in sigself bestaan nie. Die werklikheid word geken soos dit aan die kennende gees verskyn. Kennis is daarom altyd die resultaat van die bewussyn se verwerking van die empiriese gegewens (vgl Dreyer 1989:343). Kennis bevat dus elemente van rede èn ervaring en is as sodanig sekuur. Kant se interpretasie van die menslike ervaring was dat die bowesintuiglike werklikheid nie geken kan word nie, behalwe by wyse van analogiese spreke of metaforiese taal. Hiervolgens is teologie dus nie alleen sonder metafore onmoontlik nie, maar is dit ook die rede waarom teoloë in hulle teorieë oor die funksionele aard van God se teenwoordigheid by sy skepping nie in terme van absolute en ewigdurende proposisies moet dink nie. Verskeidenheid en verdraagsaamheid pas dus by die teologie (Van Aarde 1989d:13).

Bogenoemde insig van Kant impliseer dus dat godsdienstige waardes altyd by wyse van analogiese taal, gelykenisse, metafore en ander simbole gekommunikeer word. 'n Uitspraak oor God kan daarom nooit op 'n ander manier gedoen word as in terme van metaforisiteit ( $\mathrm{d} w \mathrm{~s}$ analogiese- of simboliese taal, of $\mathrm{d} \mathrm{m} v$ metafore) nie. Ontwikkeling op die gebied van die sosiologie en dan in die besonder dié van die kennissosiologie, het die mens verder geleer dat waardes wat so in tekste uitgedruk word as legitimering dien van teoretiese oortuigings met betrekking tot die metafisiese werklikheid, dit wil sê met betrekking tot die eerste beginsels van die werklikheid, die essensie van die bestaan (Van Aarde 1991b:6).

Die begrippe 'transendensie' (transendente werklikheid) en 'metafisika' (metafisiese werklikheid) is volgens Van Aarde (1991b:7) daarom hier van belang. Som- 
mige teoloë probeer die woord 'metafisies' vermy wanneer daar uitsprake oor God gemaak word en gebruik eerder die woord 'transendent'. Die rede hiervoor is die feit dat die begrip 'metafisies' nie betrekking hoef te hê op God nie. Die begrip 'transendent' het op sy beurt egter altyd die implikasie dat die essensie buite die eksistensie is, dit wil sê buite dit wat waarneembaar is. Die essensie lê aan die 'anderkant' van die waarneembare, wat beteken dat eksistensie en essensie geskei word. Die waarheid lê dus nie in die waarneembare (eksistensie) nie, maar in die essensie 'agter' die eksistensie (vgl bv Paulus in hierdie verband; kyk Van Aarde 1991b:6; 1991c:2). Die essensie (waarheid) kan daarom alleen gevind word in die verhouding van die fisiese (sigbare) tot die metafisiese (onsigbare) (vgl bv ook die begrip 'referensiële betekenis' in die 'herontdekking' van Plato; kyk Van Aarde 1991b:6).

In terme van bogenoemde was Kant van mening dat God nie as 'ding' waargeneem kan word nie. God kan dus nie as 'objek' bestudeer word nie en oorskry dus die grense van die wetenskap. Indien die mens sou sê dat God wel bestudeer kan word, dit wil sê 'n 'wêreldding' is, sou dit beteken dat God aan sy skepping gelykgestel word (kyk weer 'organismiese holisme' hierbo). Volgens Van Aarde (1991b: 6) behoort die mens daarom in ag te neem dat waaragtige eksistensie, dit wil sê die essensie van eksistensie, nie in die mens self of enigiets anders in die skepping geleë is nie, maar in God. Die teoloog konkludeer daarom dat die essensie by God te vind is. Hy alleen is die 'ultimate', die 'hoogste goed'. Omdat God die 'hoogste goed' is, moet die mens dus die rug op homself keer - en dit kan die mens alleen doen indien hy homself as skepsel met beperkinge ken (Van Aarde 1991b:6).

Volgens Van Aarde (1991b:6) het bogenoemde beginsels in die teologie ná die invloed van die filosoof Kant duidelik begin word. Die mens het besef dat God nie 'n 'ding', 'n deel van die skepping is nie. Maar watter uitsprake kan dan oor God in hierdie wêreld gemaak word? Daar kan alleen uitsprake oor God gemaak word waar daar rekening gehou word met die 'Existenzverständnis' van die mens, dit wil sê hoe 'n mens 'waaragtig' bestaan, weg van die mens. Selbstverständnis is dus nodig voordat die mens tot Existenzverständnis kan kom. Teologie is daarom in 'n sekere sin antropologie, maar dit is ook nie net antropologie nie. Teologie kan egter nie bestudeer word sonder om ook die antropologie te bestudeer nie. Die uitspraak 'God is liefde' kan hier as voorbeeld dien. Word God in so 'n uitspraak tot 'n 'ding' gemaak? Nee, maar dit is omdat die mens weet hoe beperk hy in sy liefde is, dat hy weet dat God wat gans anders as hy is, onbegrens in liefde is. Op hierdie wyse keer die mens dus die rug op homself om 'n uitspraak oor God te maak. Om so van God te praat is om van analogiese taal gebruik te maak, om die 'commitments' wat in jou lewe bestaan, tot uitdrukking te bring. 'Wees lief' is ' $n$ 'commitment' wat in metaforiese taal na analogie van God uitgedruk word. Die teologie kan dus nie sonder me- 
tafore nie. Hierdie insig beskou Van Aarde (1991b:7) as die hart van die Reformasie. In die teologie-geskiedenis was dit die Reformasie wat die onmag van die mens voor die oormag van God beklemtoon het.

Volgens Van Aarde (1989d:13-15) skep die bewustelike gebruikmaking van metaforisiteit in teologiese teorievorming nie alleen die moontlikheid dat die teologie deurentyd werklikheidsbetrokke kan wees nie, maar ook dat die eksistensie van die mens voor God bewustelik verdiskonteer word. Metaforiese taal oor God toon aan hoe mense coram Deo, ofte wel in die teenwoordigheid van God, lewe (Van Aarde 1989d:15).

Metaforiese taal oor God is wat Schleiermacher (kyk Klemm 1986:8-9) in 'n effens ander verband reflektiewe taal noem. Schleiermacher praat ook van die responderende ervaring as verduideliking van wat hy met sy baie bekende begrip 'die gevoel van absolute afhanklikheid' (das schlechtinnige Abhängigkeitsgefühl) bedoel (kyk Venter 1989:17-27). Dit is 'n ervaring wat bestaan in terme van die menslike selfbewussyn om van God afhanklik te wees (gottgläubige Selbstbewusstsein). In hierdie verband maak Schleiermacher 'n onderskeid tussen die begrippe 'gevoel' en 'emosie' om iets van die mens se verhouding met God uit te druk. Hy is volgens Van Aarde (1991b:7) die eerste teoloog wat Kant se idee van die gansandersheid van God probeer verdiskonteer het. Op grond van hierdie onderskeid meen baie teoloë (ook in die Hervormde Kerk) dat Schleiermacher 'n metodis/ervaringsteoloog is. Volgens Schleiermacher is emosie en gevoel egter nie dieselfde saak nie. Emosie word gewek deur waarneming van objekte en is altyd wisselend omdat waarneming wisselend is. Om 'n konstante te vind te midde van wisselende waarneming en wisselende emosie wat nie afhanklik is van die objek(te) wat bestudeer word nie, moet dit in 'n nie-objek, te wete God, gevind word. So 'n konstante is die mens se afhanklikheidsgevoel voor God. Dit is 'n gevoel binne-in hom van om afhanklik te wees. Hierdie gevoel kan uitgespreek word in die teologie, maar is gegrond in wat nie waargeneem kan word nie, te wete in God. Daarom kan die mens te midde van wisselende emosies (bv vreugde of pyn) gelowig voor God leef omdat die gawe van die geloof konstant die mens bewus hou dat God teenwoordig is en dat die gelowige afhanklik van en voor God is.

Hierdie afhanklikheidsgevoel by Schleiermacher word uitgedruk in terme van metafore en hy verwys daarna as 'reflektiewe taal'. Self verduidelik Van Aarde dit soos volg: Iemand kan byvoorbeeld sê hy het op grond van God se liefde lief en so gryp na die bo-emosionele, die nie-wisselende, want God se liefde bly trou. Daarom is teologiese taal analogiese taal, metafore wat probeer sê wat geloof is en wat nie afhanklik is van blote waarneming nie (Van Aarde 1991b:8). Vanuit hierdie perspektief meen Van Aarde (1991b:8) het die teologie as wetenskap dus 'n metafisiese 
basis. Hy stem daarom nie saam met teoloë wat van mening is dat wanneer daar oor God gepraat word, die woord 'metafisiese' nie gebruik mag word nie. Want wanneer daar van 'metafisies' gepraat word, word nie alleen 'n Platoniese denksisteem bedoel nie, maar word daar ook aangesluit by die dialektiese teologie wat altyd die gansandere God voorop hou (Van Aarde 1991b:8; kyk ook Van Aarde 1991c:2).

Volgens Van Aarde (1989d:15) moet ingesien word dat Schleiermacher die gelowige se bestaan voor God in absolute afhanklikheid nie individualisties of geisoleerd sien, los van die geloofsgemeenskap waarin die individu staan nie. Die 'gevoel van absolute afhanklikheid' kan alleen binne die ruimte van die ervaring van die gemeenskap van die gelowiges gekommunikeer word. Hierdie taalgebeure is egter nie primêr teologiese taal as wetenskaplike taal nie, juis omdat in die teologie, as wetenskaplike onderneming, die bestaan van die mens voor God nie ontsluit word nie. Teologie as wetenskap is hoogstens diensbaar vir hierdie ontsluiting en metaforisiteit in teologievorming bied daarom 'n soort operasionele basis vanwaar hierdie diens gelewer kan word. Die reflektiewe taalgebeure waar die bestaan van die mens voor God ontsluit word, vind daarom vir Schleiermacher plaas in die preekgebeure (kyk Van Aarde 1989d:15).

Laasgenoemde insig van Schleiermacher word deur Van Aarde (1991b:1-3; $1991 \mathrm{~b}: \mathrm{l}$ ) in sy eie kenteoretiese raamwerk verdiskonteer in terme van die onderskeid tussen teologie en geloof. Volgens Van Aarde (1991b:1) is teologie altyd 'n wetenskaplike onderneming, dit wil sê bewustelike refleksie of besinning. Daarenteen is geloof meer as kennis van God se Woord en meer as die doen van God se wil. Geloof is om absoluut innig van God afhanklik te wees, alhoewel dit nie bloot emosie is nie. Die geloof van 'n teoloog is 'n 'commitment', 'n soort van tweede-naiwiteit. Onderskeid moet dus getref word tussen 'n voor-wetenskaplike naïwiteit, 'n wetenskaplike proses van besinning of refleksie ( $\mathrm{d}$ w s die teologie) en die geloof, dit wil sê, 'n tweede-naïwiteit. Geloof en teologie is dus nie dieselfde aangeleentheid nie. Die 'commitment' wat die gelowige maak, maak hy of as 'n individualis (wat deur die gemeenskap verwerp of gedeel kan word) $\partial f$ as 'n persoon wat deel is van die gemeenskap waarin hy staan. Geloof in terme van 'commitments' is daarom gewoonlik 'n gemeenskaplike aangeleentheid (soos wat dit na vore kom in gemeenskaplike geloofsbelydenisse).

Wanneer 'n predikant preek, is sy uitsprake vanaf die kansel in wese 'commitments', omdat dit die geloof van die prediker openbaar. Die prediker is egter altyd een van die gemeenskap waarin hy staan en wat ook glo. Daarom is dit nie as sodanig teologie wat die inhoud vorm van wat gepreek word nie, maar die 'commitments' van die teoloog. 'n Duidelike onderskeid moet dus getref word tussen ener- 
syds bewustelike refleksie oor teologiese aangeleenthede ( $\mathrm{d}$ w $\mathrm{s}$ dit wat die teologie is), soos byvoorbeeld die verhouding God en mens, en andersyds waar iemand hom/haar kinderlik gelowig verbind aan bepaalde 'commitments' (Van Aarde 1991b:1).

Enige teoloog is (en behoort) voortdurend besig (te wees) om na te dink oor die werklikheid wat hy/sy waarneem in terme van die verhouding God en mens. Hierdie waarneming het die reformatoriese teoloog vanweë sy tradisie klaar laat bind aan 'n gemeenskaplike 'commitment' wat hy met ander gemaak het, te wete dat sy waarneming gekontroleer en gekorrigeer kan word deur 'n eksterne bron, genoem die Bybel. Die Bybel (as bron) kan beskou word as die 'klassieke model' (vgl Tracy 1981:108) van die mens se teologiebeoefening. Met 'klassiek' word bedoel dit wat in die verlede klassiek geword het, maar nog vandag, dit wil sê oor die tyd heen, betekenis behou het en vandag nog van betekenis is. Met die Bybel as 'klassieke model' bedoel ons dus dat ons 'n 'commitment' gemaak het dat ons uitsprake vandag meetbaar is aan iets wat in die verlede reeds gesê is, wat in 'n dokument opgeteken is, naamlik die Bybel.

Van Aarde (1991b:2) meen dat die individuele gelowige nie alleen hierdie 'commitment' van die geloofsgemeenskap waarin hy staan, kan breek nie. Hy beskou dit as ewe belangrik om daarop te wys dat die beklemtoning van eksistensialisme in die teologie en geloof nie op individualisme behoort uit te loop nie. Dit sou byvoorbeeld daarop neerkom dat indien 'n teoloog sou besluit dat die klassieke model van die geloofsgemeenskap waarin hy staan, of aspekte daarvan, nie meer die model is in terme waarvan hy sy uitsprake hoef te meet nie, hy deur die geloofsgemeenskap as vreemd ervaar sal word. Hierdie individu kan egter die geloofsgemeenskap lei (met die moontlikheid om verwerp te word) om die klassieke model of aspekte daarvan te herinterpreteer of te verruim. Slegs as span kan die geloofsgemeenskap dus besluit dat hulle afstand wil doen van aspekte van 'n bepaalde klassieke model in terme waarmee hulle hulle teologiese uitsprake wil kontroleer.

Op grond van bogenoemde uitgangspunt het Van Aarde (1991b:2) 'n probleem met teoloë wat byvoorbeeld bewustelik aan 'n bepaalde gedefinieerde geloofsgemeenskap wil behoort (bv die Gereformeerde of Hervormde Kerk), maar nie bereid is om onder andere die belang van die klassieke model vir daardie geloofsgemeenskap in hulle teologiese uitsprake te verdiskonteer nie. Vir hom is daar' $n$ soort van onegtheid teenwoordig wanneer teoloë binne 'n bepaalde ruimte sit waar mense saam ' $n$ 'commitment' gemaak het en dan teologie op so 'n wyse beoefen asof daar nie 'n klassieke model bestaan nie. Indien die rol van die geloofsgemeenskap erken word, moet daar altyd met die tradisie van hierdie gemeenskap erns gemaak word, soos in sy geval die reformatoriese en meer spesifiek die Hervormde tradisie. 
Die waardes en tradisies van sowel die geloofsgemeenskap as die Reformasie moet dus bewustelik verdiskonteer word in die wyse waarop teologie beoefen word, anders is die teoloog oneg en moet hy die Reformasie verbygaan. Die teoloog hoef egter volgens hom nie altyd met die tradisie saam te stem nie, maar behoort dit te verdiskonteer en aan te toon waar hy van die tradisie wil afwyk.

Bogenoemde lei tot die insig dat teologie en belydenis altyd 'n gemeenskaplike aangeleentheid is. Van Aarde se gebruik van die begrip 'gemeenskap' bring hom op sy beurt weer uit by die begrip 'sosiologie'. Op grond hiervan moet enige vorm van kennis (wete) as 'n sosiale proses gesien word. So gesien, is kennis gegewens of feite wat na vore gekom het en geken word in 'n raamwerk van 'n bepaalde dinkproses van kollektiewe denke. 'n Deelgenootskap met geleerdes (en 'n gemeenskap) bepaal dus dat iemand waarneem soos hy waarneem en dit bepaal die produk van sy wetenskapsbeoefening. Wetenskap is dus 'n sosiale aangeleentheid en proses.

In vandag se postmoderne wêreld met sy mondiale kultuur bestaan daar egter verskillende sosiologiese gemeenskappe met verskillende interpretatiewe raamwerke. Die begrippe 'relativisme' en 'toleransie' is daarom hier van belang. 'Relativisme' sou beteken dat die resultate van verskillende blikke op die werklikheid almal 'n gelyke kans tot waarheid sou hê. 'n Wetenskaplike teorie se sukses is egter geleë in sy verklaringsmoontlikheid van bepaalde modelprobleme. 'n Toleransie vir ander interpretatiewe raamwerke is dus nodig ter wille van progressie in die soeke na waarheid. Waarheid is so gesien meer-dimensioneel, omdat dit dan onder andere ook lê in terme van die aantoon van leemtes (Van Aarde 1991b:3).

Uit bogenoemde is die epistemologie van waaruit Van Aarde teologie wil beoefen, myns insies duidelik. Sy kenteoretiese paradigma verdiskonteer nie alleen die reformatoriese en dialektiese tradisie waarin hy staan nie, maar ook die werklikheidsbetrokkenheid wat die teologie in ons postmoderne mondiale kultuur moet hê. Verder neem dit die gansandere God in ag, die eie-aard van die Christelike geloof, asook die eis om nie net op die kognitiewe te bou nie, maar ook op die emotiewe en die pragmatiese. Dit verklaar dan ook hoekom hy, soos Schleiermacher, sy posisie as professor in die teologie nooit anders sal wil sien as om ook bedienaar van die Woord te wees nie.

\subsection{Teologie}

In die vorige afdeling het dit duidelik geword watter geweldige invloed die werk van Kant en Schleiermacher op Van Aarde gehad het wat betref sy kenteoretiese aannames. Dit is dan ook nie vreemd dat hy, in die wyse waarop hy meen die Bybelse teologie behoort beoefen te word, ook sy aanknopingspunte by Kant en Schleier- 
macher vind nie. Dit is egter ook duidelik dat die werke van Bultmann en Barth 'n besliste invloed op hom gehad het.

In die beoefening van die Bybelse teologie vind Van Aarde sy uitgangspunt in die reeds genoemde insig van Kant dat God nie geken kan word anders as by wyse van analogiese taal, dit wil sê metaforiese spreke nie. Vir hom is 'teologie dus nie sonder metafore moontlik nie' (Van Aarde 1989d:13). In sy lees van literatuur wat handel oor die rol wat metaforisiteit in teologiese teorievorming inneem, meen Van Aarde (1989d:15) dat een saak hom in hierdie literatuur telkens opgeval het, te wete die 'korrelasie...tussen metaforiese taal oor God en die eksistensie van die mens'. Wat die mens oor God sê, is altyd 'n uitdrukking van 'n relasionele verhouding tussen God en die mens. Teologie het dus te make met die wyse waarop mense hulle in verhouding met God sien.

In hierdie verband sluit Van Aarde (1991b:7) aan by veral Schleiermacher en Bultmann. Metaforiese taal oor God is wat Schleiermacher (kyk Klemm 1986:8-9) 'gottgläubige Selbstbewusstsein' en Bultmann (1948:23) 'mythische Heilsgeschehen' noem (kyk ook Pelser 1987:162-191). Bultmann (1952:180) beskryf die term 'mite' as 'ein ganz bestimmtes geschichtliches Phänomen' en 'mitologie' as 'ein ganz bestimmte Denkweise'. Die dialektiese verband tussen 'mite' en 'mitologie' is daarin geleë dat die mite as die literêre neerslag van die mitologiese wêreldbeeld gesien kan word. Bultmann is verder van mening dat 'mythische Denken' die 'Gegenbegriff' van 'wissenschaftliche Denke' is.

Mitologie bestaan dus nie sonder mites nie en mites kan nie geïdentifiseer word sonder om die teks te lees nie. In terme van die godsdiens het die mitologiese wêreldbeeld betrekking op die 'terrein' waar God en die mens mekaar ontmoet. Al kan God nie gesien word nie, al is God 'buite' die mens se waarnemingsvermoë, tree God en die mens met mekaar in verbinding in terme van mitiese spreke. Mitologie sal dus altyd verband hou met die visie op die werklikheid en die verhouding tussen God en mens kan nie anders gesien word as in terme van die mens se visie van die werklikheid nie. So gesien beteken dit dat mite, as literêre neerslag van die mitologiese wêreldbeeld, 'n aanduiding van die sosiale wêreld is. 'n Ondersoek van die sosiale wêreld van die Bybel (tekste in hierdie geval) is dus 'n aanduiding van die verhouding God en mens wat tot uitdrukking kom. Vervolgens sal aangetoon word dat Van Aarde dan ook by bogenoemde insigte van Kant, Schleiermacher en Bultmann aansluit in sy keuse vir die kennissosiologie as model om tekste sosiaal-wetenskaplik, in terme van grondmetafore, te lees.

Om die metaforiese spreke oor God, soos dit in tekste neerslag gevind het, in 'n Bybelse teologie te verdiskonteer, sluit hy aan by Weinrich (in Sellin 1982:384). Weinrich is van mening dat 'n definisie van die metafoor net in die tekssemantiek 
moontlik is, omdat die definisie van 'n metafoor konteks veronderstel. Die rede hiervoor is dat die subjek en predikaat van 'n metafoor, wat altyd in ' $n$ analogiese verband met mekaar staan, bymekaar moet pas sodat 'n analogic moontlik is. Die subjek en predikaat van 'n metafoor bepaal mekaar dus wedersyds semanties. Dit is op grond van hierdie eienskap van 'n metafoor dat Paul Ricoeur meen dat 'n metafoor nie slegs 'n diskoersverskynsel is nie, maar ook sin stig. Weinrich praat van die skeppende werk (die demiungische Leistung) van metafore. 'n Metafoor bevraagteken die gebruiklike taalkundige kategorisering en bied tegelykertyd nuwe kategorisering aan (dit oriënteer om daarna te disoriënteer met die doel om te reoriënteer [Ricoeur 1975:122-128]) en tref daarom altyd as 'n verrassing (Ricoeur 1975:34). 'n Mens sou ook kon sê dat 'n goeie metafoor deur middel van skokeffek werk (vgl Hopkins 1989:215).

Metafore is dus beelde van woorde. Volgens Ricoeur skep die mens sulke beelde om egte waarneming vas te vang en te beskryf. Iets wat in die bekende kultuur waarneembaar en kenbaar is (die vehicle, die beeldhelfte), word in taal skeppend en tegelykertyd spannend gekoppel aan iets wat ons direk of intuïtief aanvoel (die tenor, die saakhelfte). 'God is 'n rots' sou dus 'n eenvoudige voorbeeld van 'n metafoor wees. In 'n metafoor word nuwe betekenis geskep en dit stel die mens in staat om weer 'n greep op die werklikheid te kry.

Alhoewel Van Aarde (1989d:9) nie as sodanig gemteresseerd is in die taalkundig korrekte definisie van 'n metafoor nie, meen hy dat dit wel belangrik is om te onthou 'dat ' $n$ metafoor meer kan wees as 'n enkele woord; dit is in elk geval altyd 'n segging. En 'n segging kan enkelvoudig wees of uitgebreid, soos byvoorbeeld 'n gelykenis van Jesus' (Van Aarde 1989d:9). Baie simplisties gesien, 'is 'n metafoor om een ding te sien as iets anders, om voor te gee hierdie is daardie, omdat ons nie duidelik weet hoe om oor hierdie te praat nie en daarom maak ons van daardie gebruik om oor hierdie te praat' (Van Aarde 1989d:9). Omdat die mens min van iets (die Ding an sich, ofte wel die noumenon in Kantiaanse terme) weet, maak hy gebruik van iets waarvan hy meer weet (die Erscheinung, ofte wel die phenomenon) om iets sinvol te kan sê oor die ding waarvan hy min weet

In die gebruikmaking van die metaforisiteit van tekste in Bybelse teologie, meen Van Aarde (1989d:14; 1991b:13-14) dat dit belangrik is om te onderskei tussen metafore en grondmetafore. Alle metafore deel een gemeenskaplike eienskap, naamlik dat dit verklarend is: Dit druk nie alleen syn of fenomenologiese wyse uit nie, maar ook die essensiële aard van eksistensie (Van Aarde 1991b:14). Sein en Dasein word in die metafoor bymekaar uitgebring en so word die mens se essensiële bestaan tot uitdrukking gebring. As voorbeeld kan dien die reeds gemelde metafoor 'God is 'n rots'. As die mens sê dat God 'n rots is, sê hy daarmee nie dat God 'ver- 
dinglik' word nie, maar dat feilbare mense nie werklik rotse is nie. Maar omdat God (soos) 'n rots is, kan daar op Hom vertrou word. Die mens kan dus voor God bestaan deur vertrouend op Hom staat te maak. Deur so iets oor God te sê, word ook iets van die mens en sy eksistensie voor God gesê. Die metafoor skep dus die moontlikheid om die mens se eksistensie voor God op 'n kragtige manier uit te druk: 'Omdat God my Vader is, sal hy vir my sorg.'

Teenoor gewone metafore het die grondmetafoor egter twee eiendomlike eienskappe, te wete dat dit generies is en blywende krag het (vgl McFague, in Hopkins 1989:215). ' $n$ Grondmetafoor is generies omdat dit die moontlikheid in hom het om, net soos woorde hulle betekenisse vind in die sametrek van ander woorde binne 'n semantiese veld ( $\mathrm{d} w \mathrm{~s}$ dinge beteken in terme van hulle generiese en onderskeidende betekenismoontlikhede), ander metafore na hom te trek (kyk Van Aarde 1991b:14-15). Die grondmetafoor kan dus dien om 'n 'kompleks van metafore in dieselfde verwysingsveld te groepeer en te verstaan' (Van Aarde 1989d:14). Verder het grondmetafore blywende krag omdat dit 'in opeenvolgende tye gehandhaaf [kan] word terwyl die verwysing daarvan radikaal kan verander' (Van Aarde 1989d: 13). 'n Voorbeeld van 'n Bybelse metafoor wat blywende krag het, maar ook generies is, is volgens Van Aarde (1989d:13) 'om God sinvol te ken na aanleiding van ons ervaring in die lewe van die gesin'. God is ons Vader en Jesus is sy unieke Seun. Deur die inwoning van God se Gees kry ons deel aan hierdie 'seunskap'. Die gevolg hiervan is dat ons kinders van God en broers en susters van mekaar word. So word die metafoor 'tempel' ook met die gemeente as 'huisgesin van God' (vgl Ef 2:11-22) in verband gebring. Die grondmetafoor 'huis' trek byvoorbeeld ander metafore soos 'God is liefde', 'om te vertrou' in dieselfde metafoor in (kyk Van Aarde 1991b:15). Die relatiewe aard van die metafoor stel ons verder in staat om 'n simbool (soos die tempel) te behou, terwyl ander dimensies van sy referensiële betekenis beklemtoon kan word. Volgens Van Aarde (1989d:13) skep die bewustelike gebruikmaking van metaforisiteit in teologiese teorievorming dus die moontlikheid dat die teologie deurentyd werklikheidsbetrokke kan wees. Metafore kan immers verander terwyl die inhoude daarvan saaklik dieselfde kan bly (kyk Van Aarde 1989d:13).

Dit is dan ook in hierdie verband dat Van Aarde (1989d:14) 'na die metaforiese taal in die Nuwe Testament oor God se teenwoordigheid na aanleiding van die konsep "tempel" verwys as 'n grondmetafoor. Volgens hom is dit duidelik dat daar dikwels in die Ou en Nuwe Testament oor die teenwoordigheid van God by die gelowiges as 'n geloofsgemeenskap na analogie van 'tempel' en 'huisgesin van God' gepraat word (Van Aarde 1989d:6). Sy tese in hierdie verband is dat daar 'n tendens wat in hierdie verband in die Ou Testament (en tussentestamentêre literatuur) waarneembaar is, in die Nuwe Testamant metafories verder gevoer is: 'Dit is naam- 
lik die feit dat die beperkende maatreëls met betrekking tot die toegang tot die fisiese tempelgebou matiger geraak het sodat daar van die tendens van vernuiming van die tempel gepraat kan word' (Van Aarde 1989d:6). Hy is van mening dat hierdie verruimende effek telkens met behulp van nuwe metafore geskep is, wat elke keer 'n skokeffek sou gehad het. Hierdie verruiming van die tempel word soos volg beskryf:

Hoewel die tempel 'n fisiese gebou was, was dit ook 'n teologiese konstruksie. Na die vernietiging van die tempel van Salomo idealiseer Esegiël (Eseg 44:9) 'n nuwe tempel, alhoewel nog met die voorbehoud dat geen nie-Israeliet in die tempel mag kom nie. In Jesaja $56: 7$ sien ons egter dat die tempel 'n 'huis van gebed' genoem word wat wel toeganklik is vir nie-Israeliete. In Jesaja 66:1 word die toegang tot die tempel verder verruim deurdat God se teenwoordigheid nie tot die tempel as gebou beperk word nie (vgl ook Ps 150:6).

(Van Aarde 1989d:6-8, 17-19)

Hierdie verruimende tendens se begin kan verder gesien word in die feit dat in Nehemia se tyd die tempelpersoneel die opdrag gekry het om die herboude mure van Jerusalem te wy, so asof die heiligdom verruim geraak het. Die stad word dus so, na analogie van God se teenwoordigheid, 'heilig' genoem (vgl Lev 11:44). Ook staan daar in Nehemia (en in ander dele van die Kronistiese vertellinge) dat die volksvergadering begin het om sy eksklusiwiteit prys te gee, deurdat vroue en kinders ook nou ingesluit word (vgl Esra 10:1; Neh 8:2-17). Ook in die tussentestamentêre literatuur is daar heelwat opmerkings oor hoe die mens buite die kultus om met God versoen kon word (kyk Breytenbach 1989:199-200).

Wat die Judaïsme betref, het hierdie verruimende tendens egter ook sy grens gehad. So het Philo byvoorbeeld Deuteronomium 23:1-8 vergeestelik deur dit te interpreteer asof nie-Jode alleen toegang tot die tempel as proseliete kon verkry. Die nie-Jood moes dus eers ' $n$ Jood in biologiese sowel as godsdienstige sin word voordat toegang tot die tempel verkry kon word. Dit het geïmpliseer dat 'n nie-Jood eers religieus 'rein' en 'regverdig' was indien hy besny was en die Joodse sabbatdag, kalenders en feeste gehou het. Lidmaatskap tot die geloofsgemeenskap was dus dieselfde as burgerskap. Sosiale ostrasering het neergekom op die weiering van toe gang tot die tempel. Reinheidswette het die toegang tot die tempel gereguleer. Eweneens was dit streng verbode om saam met 'onrein' mense soos nie-Jode te eet, aangesien die gemeenskaplike maaltyd vir die Farisese Jood die replika was van die rituele handeling in die tempel.

Hierdie grens is egter in die Jesus-gebeure oorgesteek. Matteus vertel byvoorbeeld van die voorhangsel wat geskeur het (Matt 27:15) en die belydenis van 'n nie- 
Jood na aanleiding daarvan (Matt 27:54). Ook vertel Matteus dat Jesus 'onrein' mense soos kreupeles en blindes in die tempel gesond gemaak het en dat selfs kinders Hom in die tempel as Seun van Dawid geloof het (Matt 21:14-15). Verder het Jesus selfs saam met 'sondaars' geëet (vgl o a Luk 7:36-50). Hiermee het Jesus dan ook sy standpunt oor wie Hy reken toegang tot die tempel het, baie duidelik gemaak. Jesus se weiering om aan die voorskrifte by die maaltyd te voldoen (vgl Luk 11:38) vertel dus iets van sy houding teenoor die maatreëls by die tempel. Soos God teenwoordig is in die tempel, so is Hy ook in die huishouding en soos almal toegang tot die maaltyd het, so het almal tot die tempel. Conzelmann (1963:123) meen in dié opsig dat Lukas Jesus se houding geïnterpreteer het asof Jesus die tempel sonder verskillende voorhowe gesien het. Dit is dan ook Lukas wat vertel dat Paulus se heidensending deur die Joodse leiers gesien is as 'n aanval op die tempel in lyn met Jesus se houding, veral omdat $\mathrm{Hy}$ heidene in die tempel sou toegelaat het (vgl Hand 21:28).

Jesus se uitspraak dat Hy in staat is om die tempel in drie dae af te breek en ' $n$ ander een wat nie deur mense gemaak is nie, in drie dae op te bou (vgl o a Mark 14:58) het daartoe gelei dat sy kruisdood in hierdie lig geïnterpreteer is. Nie alleen word die instellingswoorde van die Nagmaal hiermee in verband gebring nie (vgl o a Mark 14:22), maar dra Paulus die uitspraak van Jesus dat sy liggaam die tempel van God is, oor op die liggaam van die gelowige (vgl o a 1 Kor 3:16-17). Dit is asof Paulus die in-Christus-formules hier in gedagte kon gehad het, wat allerweë beskou word as die grond vir die Nuwe-Testamentiese kerkbeskouing (kyk Bultmann 1968: 312). Dit is dan ook nie verrassend dat hierdie ekklesiologiese aspek in die Pauliniese tradisie voortgesit is nie. So lees ons in tekste uit die vroeg-katolieke periode dat daar na die Christelike geloofsgemeenskap as die huis/tempel van God verwys word (1 Pet 2:5; Ef 2:21-22). 'n Muur wat skeiding maak (Ef 2:14), soos die voorhangsel in die tempel, bestaan nie meer nie en bywoners en immigrante word almal 'medeburgers van die gelowiges en lede van die huisgesin van God' (Ef 2:19). Verder word hierdie 'heilige tempel' gekonstitueer deur die verkondiging (Ef 2:20). Op grond van dié preekervaring is daar vrye toegang tot die Vader (Ef 2:18).

Die nuwe metafore waarmee die begrip 'tempel' met God se teenwoordigheid in verband gebring is, is volgens Van Aarde (1989d:8) daarom onder andere een van die belangrikste redes hoekom die die sinagoge met die vroeë Christendom gebreek het. Die 'tempel' kan dus inderdaad een van die grondmetafore genoem word ten opsigte waarvan die die uniekheid van die vroegste Christendom beskryf kan word.

Die grondmetafoor 'tempel' kan egter ook as basis vir ' $n$ teologiese model dien waarop sistematiese teoloë kan voortbou sodat dit vir die prediking diensbaar kan wees. As basis vir die kompleks van metafore rondom die begrip 'tempel' in die 
Nuwe Testament sou die volgende kon dien: '...die korrelasie tussen die analogiese spreke dat God in 'n huis by mense woon en die eksistensie van gelowiges wat in die huis met mekaar kommunikeer, nie sodat hulle mekaar kan verstaan en liefhê nie, maar omdat hulle mekaar verstaan en liefhet' (Van Aarde 1989d:17).

Vir Van Aarde (1989d:9) is dit op grond van bogenoemde duidelik dat metaforisiteit nie alleen groot implikasies vir die kenteorie het nie, maar ook vir teologiese teorievorming. Teologie sonder metafore blyk haas onmoontlik te wees, want wat weet die mens van God anders as dit wat hy by wyse van analogiese spreke oor God kan sê?

Teologie is derhalwe ook'n beskeie wetenskap. Verder is teologie altyd voorarbeid. Die Bybelwetenskap is nog in 'n verdere sin vooraf voorarbeid. Die teologie word eers betrokke by die werklikheid en is eers van etiese belang, nadat die bestaan van die mens voor God primèr in die preekervaring ontsluit word. Die eerste arbeid het met teologie as wetenskap te doen (Wissen), die laaste met die etiese pragmatiek in die werklikheid (Tun). Die twee aktiwiteite word begelei deur die ervaring van absolute afhanklikheid voor God (om die woorde van Schleiermacher te gebruik). Hierdie ervaring word in die preekervaring deur middel van reflektiewe taal ontsluit. Die werklikheidsbetrokkenheid van die teologie geskied daarom ook alleen op grond van en via die preekervaring. Die Bybelwetenskap identifiseer die grondmetafore waarop die ander teologiese dissiplines kan voortbou. Die predikant gebruik die resultate hiervan en op grond van sy eie responderende arbeid stel hy homself op die kansel so bloot dat die geloofsgemeenskap uitgenooi word om die geloof wat God in en deur Jesus Christus skenk, te deel en om opgebou te word tot 'n geestelike huis waarin God woon (Van Aarde 1989d:17).

Dit is dus duidelik dat Van Aarde nie alleen van oortuiging geraak het dat Bybelse Teologie sinvol in terme van grondmetafore bedryf kan word nie, maar ook dat 'n Bybelse Teologie wat van byvoorbeeld 'n eksistensialistiese of heilshistoriese grondslag uitgaan, nie dieselfde verduidelikende vermoë met die oog op die huidige tydsgewrig het nie.

\subsection{Hermeneutiek}

In afdeling 2 is aangetoon dat Van Aarde van mening is dat daar in die beoefening van enige wetenskap (en dus ook die Bybelwetenskap) 'n onlosmaaklike verband behoort te bestaan tussen epistemologie, metodologie en teleologie. 'n Wetenskaplike behoort dus met sy metode op pad te wees om na aanleiding van bepaalde vertrekpunte by 'n resultaat uit te kom. Die gehalte van 'n gekose eksegetiese model is geleë in die model se vermoë om hierdie weg te voltrek. 'n Model is egter nie nood- 
wendig voorhande nie. Dikwels moet dit eers gekonstrueer, 'gemaak' word (kyk Van Aarde 1991b:4, 12).

Om 'n model te konstrueer vooronderstel 'n teorie met betrekking tot bogenoemde kennisweg. Omdat die mens in terme van taal, taligheid of tekste bestaan, en wanneer hy/sy kommunikeer, skryf of praat, homself/haarself in taal uitdruk, is die taligheid van tekste dus van belang. In tekste word weer (ideologiese) perspektiewe gevind, dit wil sê mense wat hulle persepsies van sekere sake/idees weergegee het en in taal geartikuleer/uitgedruk het. (Die begrip 'ideologie' word met ander woorde nie hier in pejoratiewe Marxistiese of neo-Marxistiese sin gebruik nie.) Hierdie kennis, soos in 'n teks gevind, is op sy beurt 'n gemeenskaplike of sosiologiese aangeleentheid. Breedweg gesien sal 'n gekose model dus eerstens voorsiening maak vir 'n teorie oor antieke literêre tekste (in die geval van die Bybelwetenskap) en tweedens vir 'n teorie oor menslike persepsies (ideologieë, mitologieë of teologieë) wat in 'n bepaalde sosiale konteks tot stand kom.

Modelle wat op die gebied van die sosiale wetenskappe diensbaar is, sal daarom noodwendig gekombineer moet word met modelle van historiese en linguistiese aard. Die begrip 'interdissiplinêr' is daarom hier van belang. 'n Goeie voorbeeld van 'n interdissiplinêre model is volgens Van Aarde (1991b:13) die werk van die Nuwe-Testamentikus J H Elliott (o a 1986:1-33) wat 'n onderskeid tref tussen die strategie (doelbewuste literêre ontwerp van die teks in terme van effek) en situasie (mikro- en makrovlak van sosiale konteks). Dit is dus 'n model wat beide 'n sosiaalwetenskaplike en literêre gerigtheid het. Met 'strategie' word hier verwys na sekere tegnieke in 'n teks wat kommunikasie aanhelp. Die analise van die strategie van 'n teks kom neer op 'n analise van die poëtiek van 'n teks (hoe 'n teks 'gebou' is). Omdat 'n literêre teks uiteraard bedoel is om te kommunikeer, dit wil sê die produk is van 'n sosiale gemeenskap, is die bestudering van die kommunikatiewe strategie van die teks alleen egter nie genoeg nie. Hierdie strategie moet ook gelees word in terme van die sosiale wêreld waarin die strategie gebore is en in terme waarvan die teks wil kommunikeer. 'Teks' sowel as 'strategie' is dus 'n produk van die sosiale wêreld. Die strategie van 'n teks is verder onder andere gerig op die verandering van aspekte van die sosiale wêreld waarin dit kommunikeer. Die analise van die makrososiale konteks (buitetekstuele wêreld, bv eerste-eeuse Mediterreense wêreld) en die mikrososiale konteks (binnetekstuele wêreld, $\mathrm{d}$ w s 'n bepaalde Evangelie se perspektief op die eerste-eeuse Mediterreense wêreld) is dus ook van belang. In die sosiaal-wetenskaplike model wat ontwerp word, moet daar voorsiening gemaak word vir'n perspektief op die makrowêreld vanuit die mikrowêreld. Die teks verteenwoordig met ander woorde 'n perspektief op die makrowêreld en is nie 'n regstreekse weergawe daarvan nie. Alhoewel die makrowêreld nie maklik vinnig 
verander nie, is byvoorbeeld 'n Evangelie (met sy eie narratiewe/mikroskopiese wêreld) 'n voorbeeld van hoe die makrowêreld waargeneem word en is dit ook 'n poging om aspekte van die makrowêreld te verander. Volgens Van Aarde (1991b:13) sal 'n eksegetiese model wat bogenoemde sake wil verdiskonteer, daarom nie anders kan as om die 'teks' sowel as die 'sosiale konteks' in ag te neem nie.

Om die sosiale konteks van tekste tot hulle reg te laat kom, verkies Van Aarde om sosiaal-wetenskaplik te werk en nie sosio-histories nie (kyk Van Aarde 1991b: 17). In sy keuse vir 'n sosiaal-wetenskaplike model laat hy hom lei deur sy kenteoretiese uitgangspunte. In afdelings 2 en 3 is reeds aangetoon dat hy klem lê op Kant se insig dat God slegs in terme van metaforiese spreke kenbaar is, op Schleiermacher se begrip 'responderende ervaring', en Bultmann se onderskeid tussen 'mitologie' en 'mite'. Volgens Van Aarde (1991b:15) kan die kennissosiologie (as teorie in die sosiologie hoe iemand tot kennis kom) in 'n sekere sin gesien word as 'n ontwikkeling van die insigte van Kant, Schleiermacher en Bultmann. Die kennissosiologie gaan van die standpunt uit dat die mens se verstaan van die simboliese universum neerslag vind in sy sosiale instellings. In terme van die kennissosiologie is die mite 'n komponent van die sosiale universum en die mitologie 'n komponent van die simboliese universum. Wat die kennissosiologie dus vandag in terme van die sosiologie van kennis formuleer, is daarom reeds deur iemand soos Bultmann geformuleer, hoewel op 'n ander manier. Volgens Van Aarde bou die kennissosiologie dus voort op insigte wat by Bultmann voorkom deurdat aspekte van sosiale instellings gesien word as metaforiese uitdrukkinge van die dialektiese verhouding God-mens. Die sosiale universum staan dus in 'n dialektiese verhouding met die simboliese universum.

Van Aarde wil kennissosiologie as 'n model gebruik omdat dit 'n handige teorie is wat ons in staat stel om te sien hoe skrywers van die Bybel oor God gedink het. Sy sosiaal-wetenskaplike model kom kortliks op die volgende neer (kyk o a Van Aarde 1991b:5-7, 13-17): Die kennissosiologie gaan van die standpunt uit dat die sosiale wêreld die produk is van die simboliese wêreld. Verder meen hy het die kulturele antropologie die mens geleer dat die sosiale universum in terme van sosiale instellings beskryf kan word (Van Aarde 1991a:13). Hy sluit by die Noord-Amerikaanse Nuwe-Testamentikus, Bruce Malina (1986:152-153), aan wat van mening is dat daar ten minste vier sosiale instellings in enige samelewing voorkom, te wete die kulturele, politieke, ekonomiese en godsdienstige. Hy is van oortuiging dat in die eerste-eeuse Mediterreense wêreld die familiale die dominante kulturele instelling was (kyk o a ook Hollenbach 1987:50-63).

Mense, sake en plekke verteenwoordig/verbeeld sekere instellings. Instellings verteenwoordig op hulle beurt sekere belange van mense, dinge en plekke. Hierdie 
instellings is gedurig in konflik met mekaar, veral omdat daar verskillende perspektiewe op die samelewing bestaan. Hierdie perspektiewe kan in die sosiologie deur middel van verskillende teorieë beskryf word. 'n Voorbeeld hiervan is die konflikteorie wat belange-botsings bestudeer. Die strukturele funksionalisme as teorie help om die konflik te verklaar in terme van ewewigsoekende waardes. Van Aarde (1991b:13) meen dat die kennissosiologiese model wat rekening hou met konflikte in 'n samelewing waar godsdienstige belange/waardes op die spel is, ook in ag kan neem dat belange en waardes verbeeld word in terme van sekere simbole.

Mense wat rolle in sosiale instellings beklee, vervul 'n sosiale status. Die begrip 'status' is dinamies omdat dit verband hou met iemand wat aan 'n bepaalde rolverwagting voldoen. Dié rolverwagting word deur die gemeenskap bepaal. Eer en skaamte kom persone toe afhangende van die feit of hulle aan hulle spesifieke rolverwagtings voldoen. Die gemeenskap se rolverwagting bepaal verder dat 'n persoon nie op sigself kan bestaan nie. Individualisme is in 'n sekere sin nie moontlik nie. Die persoonlikheid van die Mediterreense mens moet 'in verhouding met', dit wil sê as 'n diadiese persoonlikheid gesien word.

Die wyse waarop met hierdie metode gewerk word, bestaan uit twee stappe, te wete emics en etics. Van Aarde (kyk Van Eck 1991:664) gee hierdie begrippe in Afrikaans weer as onderskeidelik emika en etika. Eersgenoemde verwys na 'from the natives' point of view' en laasgenoemde 'from the scholar's point of view' (kyk Elliott 1986:1-33; Van Aarde 1991b:13). Die verskil tussen emika en etika dui op die verskil tussen fonemika (hoe daar gepraat en gehoor word) en fonetika (hoe die geleerde sê daar gepraat moet word). Onder emika word verder verstaan die rangskikking van relevante inligting in 'n teks (en ander tekste wat dinge soos artefakte kan insluit) onder aspekte soos konflik, instellings, klasse, rolverwagtings ensovoorts. Hierdie inligting word gevolgelik geïnterpreteer in terme van 'n gekose sosiaal-wetenskaplike model. 'n Sosiaal-wetenskaplike metode wil dus bewustelik teorieë wat in die sosiologie as selfstandige wetenskap ontwerp is, neem en dit as modelle gebruik waarvolgens tekste gelees kan word.

Voorbeelde van sodanige studies wat reeds deur Van Aarde onderneem is, word vervolgens kortliks weergegee. In 'n artikel genaamd 'Gedagtes oor die begin van die kerk - 'n geskiedenis van versoenende verskeidenheid' (Van Aarde 1987b: 325-351) gaan Van Aarde van die standpunt uit dat die hedendaagse drang om kerklike eenheidstrukture, die kerk sy menslikheid ontneem omdat dit die kerk wil laat opgaan in 'n illusionêre superstruktuur bestaande uit supermense. Hy sien die ontwikkeling van die begrip 'kerkeenheid' in die Nuwe Testament as 'n soeke na kontinuïteit met die Jesus-beweging wat konkretiseer in gemeenskaplike aanbidding tussen die Joodse en Hellenistiese Christene in die heel vroegste stadia van die vroeë 
kerk. Hy meen dat kerkeenheid vandag steeds nie gesoek hoef te word in terme van institusionele strukture nie, maar eerder in terme van versoenende verskeidenheid. In 'n artikel getiteld 'Jesus en die sosiaal-veragtes' (Van Aarde 1988d:829-846) gaan hy van die standpunt uit dat Jesus, as eerste-eeuse Jood, gesien moet word as deel van die sosiaal-veragtes van sy dag. Die sosiaal-veragtes in die eerste-eeuse Mediterreense wêreld moet egter nie anachronisties vanuit 'n hedendaagse ekonomiese of politieke perspektief beskou word nie. In dié artikel toon Van Aarde verder aan dat die sosiaal-veragtes deur Jesus gebring word om in te sien dat God ook by hulle teenwoordig is, nieteenstaande hulle neerdrukkende omstandighede en God se sogenaamde eksklusiwiteit. In 'n verdere artikel, getiteld "n Nuwe-Testamentiese begronding van die eenheid van die kerk en die eis om kerkeenheid vandag' (Van Aarde 1989c: 461-475) meen Van Aarde dat die eenheid van die kerk in die Nuwe Testament teologies, Christologies, pneumatologies en kerugmaties gefundeer was. Die Nuwe-Testamentiese kerk moet gesien word in terme van die huishouding. Die presbiter-biskoppe het, deur voort te bou op die grondslag van die apostoliese tradisie wat hulle ontvang het, soos vaders vir hulle eie huise verantwoordelikheid aanvaar. Die eenheid van die kerk was gegrond in hulle kerugma dat die huishouding van God pneumaties verbonde was aan die liggaam van die gekruisigde en opgestane Christus.

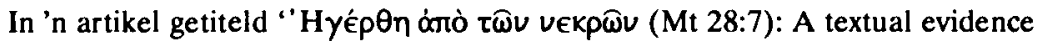
on the separation of Judaism and Christianity' (Van Aarde 1989e:219-233) stel hy vervolgens die standpunt dat historiografiese ondersoeke met betrekking tot die Evangelies, nie behoort te bestaan uit 'n ondersoek na die volgorde van episodes of selfs 'n studie van geïsoleerde Jesus-logia nie. Daar moet eerder gekyk word na individuele eenhede in logia. So 'n 'eenheid' sien Van Aarde in die woorde van die vroue in Matteus 28:7, te wete 'Hy het opgestaan uit die dood'. Sy betoog (waarop ons nie nou ingaan nie) is dat hierdie uitspraak van die vroue gesien kan word in die lig van die spanning tussen die sinagoge en die kerk in die na-70 $\mathrm{n} \mathrm{C}$ periode en dat die opstandingsverhaal in Matteus ' $n$ aanduiding is van die feit dat die breuk tussen die Judaïsme en Christendom nog nie voltrek was nie. In 'n ander artikel wat ook

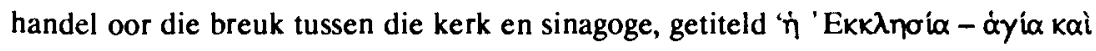

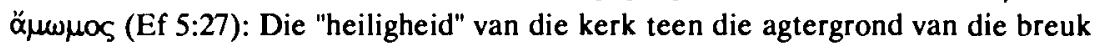
kerk-sinagoge' (Van Aarde 1990a:251-264) meen hy dat die binêre verwysing na die

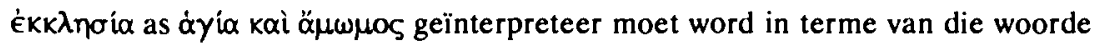

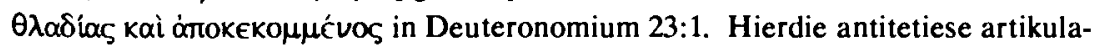
sie word deur hom geïnterpreteer teen die vroeë kerk se voorkeur vir die gebruik

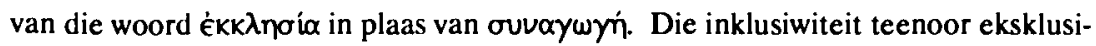

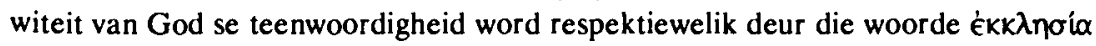




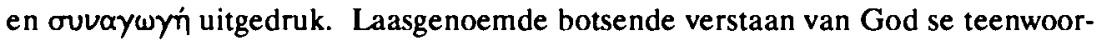
digheid was dan ook een van die belangrikste oorsake van die breuk tussen die kerk en sinagoge in die eerste en tweede eeu.

Wat die tweede aspek van sy eksegetiese metode betref, te wete die teks, gaan Van Aarde (1991b:14) van die standpunt uit dat die aard en die poëtiek (strategie) van die teks voorrang behoort te geniet (kyk o a Van Aarde [1980a]:58-73; [1980b]: 1-28; [1982a]:36-52; [1982e]:58; 1985e:441-457). Die aard van die teks dui op sy genre, byvoorbeeld die wonder, apoftegma, vertelling, brief of gelykenis. Drie voorbeelde van hoe Van Aarde die genre van 'n teks verdiskonteer, kan hier kortliks genoem genoem. In 'n bydrae wat handel oor 'n Nuwe-Testamentiese perspektief op die kind kan gesien word hoe hy die apoftegma Markus 10:13-16 hanteer (Van Aarde 1991e:1-27). ' $n$ Voorbeeld van hoe hy meen 'n wondervertelling hanteer behoort te word, kan gesien word in sy eksegese van Matteus 17:24-27, te wete die wonderbaarlike vind van 'n silwermuntstuk in die bek van 'n vis (kyk Van Aarde 1991f). Die wyse waarop hy meen 'n gelykenis (metaforiese vertelling) hanteer behoort te word, kan gevind word in 'n artikel wat in 1985 verskyn het (Van Aarde 1985e).

Wat die eksegese van die Evangelies betref, gee Van Aarde veral voorrang aan die narratologiese lees van tekste. Die keuse vir die narratologie is gegrond in die narratologie se vermoë om die kommunikasie van die teks (d w s sy strategie) te lees in terme van die makro- as mikrowêreld waarin die teks ontstaan het (buitetekstuele wêreld) sowel as in terme van die teks se eie vertelde wêreld (binnetekstuele) (kyk o a Van Aarde [1982e]:58-59). In sy narratologiese lees van tekste gee hy aandag aan onder andere die ideologiese perspektief van die verteller (kyk o a Van Aarde 1986b:62-75; 1988b:235-252), karakters (kyk o a Van Aarde 1982d:21-34), tyd (kyk o a Van Aarde 1985d:272-289; Van Eck \& Van Aarde 1989:778-800), plek (Van Aarde 1988c:89; kyk ook Van Eck 1986:139-149) en resonansie (kyk o a Van Aarde 1989f: 1-12).

Wat die lees van verteltekste betref, het Van Aarde veral twee bydraes gelewer wat hier genoem behoort te word. Met betrekking tot die ideologiese perspektief van die verteller het Van Aarde ([1982e]:60-61; 1986b:62-75; 1988b:235-252; 1988c:2227) die insig daargestel dat die begrippe 'fokalisasie' en 'narrative point of view' nie dieselfde aangeleenthede in 'n vertelteks nie. Deur veral die werke van Uspensky (1973) en Lanser (1981) te gebruik, het hy aangetoon dat die ideologiese perspektief van die verteller bestaan uit enersyds "n netwerk van temas en idees waarvolgens die verteller sy vertelde wêreld evalueer' en andersyds uit die tegnieke wat die verteller aanwend om sy ideologiese perspektief op die vertelling aan sy lesers te kommunikeer. Hierdie onderskeid impliseer dat fokalisasie, wat deur baie literatuurteoretici beskou word as dieselfde as die 'narrative point of view' van die verteller, sy 
regmatige plek in die narratologie vind as maar een van die tegnieke wat die verteller aanwend om sy vertelling in terme van sy ideologiese perspektief aan sy lesers oor te dra (kyk o a Van Aarde 1986b:62-75; Van Eck 1990:151-153). Hierdie insig van Van Aarde word veral deur Van Eck (1990:102-159), Tolmie (1991) en Du Rand (kyk o a 1990:351-366) in hulle eie lees van narratiewe tekste verdiskonteer, hoewel laasgenoemde nie altyd die nodige erkenning aan Van Aarde vir hierdie insig gee nie.

Van Aarde se tweede invloedryke bydrae op die gebied van die narratologie het te make met sy 'transparantteorie' in terme van veral die lees van die Evangelies (kyk o a Van Aarde 1986b:62-75; 1988b:235-252). Sy 'transparantteorie' kom kortliks daarop neer dat die vertelde wèreld van die onderskeie Evangelies in werklikheid 'twee wêrelde in een' is: Die voor-pase optredes van Jesus en die na-pase tradisies van die vroeë gemeente kom vermeng in die Evangelies voor en dit is nie altyd maklik van mekaar te onderskei nie (kyk o a Van Aarde 1989e:219-233).

Meer spesifieke bydraes van Van Aarde op die gebied van die lees van die Evangelies as narratiewe tekste sluit onder andere die volgende in: Matteus se tipering van die dissipels in terme van die struktuur van Matteus 13:53-17:27 (Van Aarde 1982d:21-34); 'n uiteensetting van sy narratologiese metode (Van Aarde [1982e]: 58-82); die outeurskapvraagstuk van die Johannesevangelie met die oog op die interpretasie en resepsie van die Johannesevangelie (Van Aarde 1985a:43-62); die vertellersperspektief en die 'temporele funksie' van die Ou Testament in die Matteusevangelie (Van Aarde 1985d:272-289); funksionele Jesusbenaminge in die Matteusevangelie as vertelling (Van Aarde 1987a:242-227); die ideologiese lees van Lukas 12:35-48 in terme van die ideologiese perspektief van die verteller asook die sosiale konteks van dié Evangelie (Van Aarde 1988b:235-252); die interpretasie van Matteus 17:24-27 in terme van resepsie en resonansie (Van Aarde 1989f:1-12) en 'n narratologiese analise van Markus 12:1-12 in terme van die plot van die Markusevangelie (Van Eck \& Van Aarde 1989:778-800).

Ander bydraes wat Van Aarde op die gebied van die eksegese van die Nuwe Testament gelewer het, het veral te make met 1 en 2 Tessalonisense (kyk Van Aarde 1988e: 1-36; 1989a:283-289; 1989b:290-293). In sy studie van 2 Tessalonisense is hy van mening dat hierdie brief gelees kan word teen die agtergrond van 'n anti-Saddusese polemiek (Van Aarde 1991d:1-27). Ook hier verdiskonteer hy die epistolografiese kenmerke van die Hellenistiese brief op so 'n wyse dat die groet, 'body' en slot (as poëtiek) die nodige aandag ontvang (kyk o a Van Aarde 1985b:127-136; 1991b:14).

Verder is dit duidelik dat Van Aarde die verhouding tussen eksegetiese metodologie, hermeneutiek en die homilitiek as een handeling sien. Die verhouding tus- 
sen explicatio en applicatio is nie 'n handeling van 'n eksegeet wat die aflosstokkie oorgee aan 'n hermeneut nie (vgl Van Aarde [1978a]:41-56; 1984:123-140; 1985b: 127-136). Hierdie standpunt van Van Aarde moet gesien word in terme van sy siening dat metodologie in 'n direkte verband staan met die eksegeet se epistemologie en teleologie. In verband met die verhouding tussen eksegese en homiletiek het Van Aarde (1985f:547-578) ook 'n bydrae gelewer wat handel oor 'hermeneutical fallacies' wat myns insiens spesiale vermelding moet kry. In hierdie artikel het Van Aarde oortuigend aangetoon dat die eksegeet veral moet waak teen die dwalings van intensie, genesis, referensie, affek en misplaaste konkreetheid wanneer Bybelse tekste ondersoek word. Dit is veral in hierdie artikel dat hy ingaan op die voordele ên tekortkominge van die historiese kritiek sowel as dié van moderne literatuurteorieë in terme van hulle bruikbaarheid op die gebied van die eksegese van die Evangelies.

\section{SLOTOPMERKINGS}

Van Aarde gaan in sy beoefening van die teologie uit van die standpunt dat daar 'n onlosmaaklike verband bestaan tussen epistemologie, metodologie en teleologie. Dat hierdie verband konsistent gehandhaaf word in sy beoefening van die teologie, het duidelik geword uit die volgende epistemologiese, hermeneutiese en teologiese aannames: Epistemologies gesproke is Van Aarde van mening dat die wetenskap (nog) nie 'n paradigmaverandering in terme van die Postmodernisme of (organismiese) holisme ondergaan het nie. Die huidige postmoderne en holistiese neiging in die geesteswetenskappe moet eerder gesien word as as 'n toenemende bewussyn van die plurale en ingewikkelde wèreld en werklikheid (mondiale kultuur) van vandag.

Om vandag kerk te wees in hierdie mondiale kultuur, eis van die kerk teologiebeoefening wat relevant en werklikheidsbetrokke sal wees. In terme van die insigte van Kant, Schleiermacher en Bultmann, meen Van Aarde dat die kerk hierdie taak nie anders kan verrig as in terme van die bewustelike gebruikmaking van metaforisiteit in teologiese teorievorming nie. In hierdie verband identifiseer hy sekere grondmetafore as vertrekpunt vir 'n Bybelse teologie. Van hierdie grondmetafore is onder andere die konsep 'huis van God', 'kind van God' en die 'nuwe mens' in Christus. Terwyl eersgenoemde reeds in publikasies aandag gekry het (kyk afd 3.2), word daar met groot afwagting uitgesien na sy uitwerk van laasgenoemde twee konsepte.

As hermeneutiese model maak hy tans van sosiaal-wetenskaplike teorieë gebruik en kombineer dit met teorieë van linguistiese en historiese aard. Verder ver- 
kies hy om die poëtiek (strategie) van die teks altyd in ag te neem. Die rede hiervoor is die feit dat die literêre aard van die teks (mikrotekste en makrotekste) byvoorbeeld die wonder, apoftegma, brief, gelykenis of vertelling, riglyne bevat hoe die teks uitgelê kan word. Hy is veral geïnteresseerd in die narratologiese lees van die Evangelies.

Om af te sluit: Die wyse van teologiebeoefening wat hy sedert 1979 in die Departement Nuwe-Testamentiese Wetenskap aan die Fakulteit Teologie (Afd A) gedoseer het, is 'n teologie wat nie alleen reformatories wil wees nie, maar ook dialekties-teologies en relevant. In hierdie model van teologiebeoefening neem $A \mathbf{G}$ van Aarde nie alleen die gansandersheid van God in ag nie, maar ook die eie-aard van die Christelike geloof en die postmoderne mondiale kultuur van vandag. Die doel van hierdie teologiese model is om aandag te gee aan die kognitiewe, emotiewe en pragmatiese aspekte in die teologie en die geloof. Hierdie teologiese model, sê Van Aarde, raak die kerk nie alleen in sy lied, prediking en gebed nie, maar geld ook vir die hele kerklike lewe.

\section{Literatuurverwysings}

Brauer, J 1984. Herausforderung an das Christentum heute, in Küng, H \& Tracy, D (Hrsg), Theologie - wohin? Auf dem Weg zu einem neuen Paradigma. Zürich/ Köln.

Breytenbach, C 1989. Versöhnung: Eine Studie zur paulinischen Soteriologie. Neukirchen-Vluyn: Neukirchener Verlag. (WMANT 60.)

Bultmann, R 1948. Neues Testaments und Mythologie: Das Problem der Entmythologisierung der Neuentestamentlichen Verkündigung, in Bartsch, H W (Hrsg), Kerugma und Mythos: Ein theologisches Gespräch, 15-53. Hamburg: Rein \& Heidricher-evangelischer Verlag. (ThF 1.)

--- 1952. Zum Problem der Entmythologisierung, in Bartsch, H W (Hrsg), Kerugma und Mythos, II Band: Diskussionen und Stimmen zum Problem der Entmythologisierung, 179-195. Hamburg: Herbert Reich-evangelischer Verlag. (ThF 2.)

--- [1958] 1968. Theologie des Neuen Testaments. 6. Aufl. Tübingen: Mohr.

Capra, F 1982. The turning point: Science, society and the raising culture. London: Flamingo. (Fontana Parebacks.)

--- 1989. Uncommon wisdom: Conversations with remarkable people. London: Flamingo. (Fontana Paperbacks.)

Conzelmann, H 1987. Die Apostelgeschichte. Tübingen: Mohr. (HNT.)

Du Rand, J A 1990. A socio-psychological view of the effect of the language (parole) of the Apocalypse of John. Neotestamentica 24, 351-366. 
Dreyer, P S 1989. Die wysgerige agtergrond van die Hervormde teologiese opleiding aan die Universiteit van Pretoria. HTS 45, 335-349.

Elliott, J H 1986. Social-scientific criticism of the New Testament: More on methods and models. Semeia 35, 1-33.

Hollenbach, P 1987. Defining rich and poor: Using social sciences, in Richard, K H (ed), SBL 1987 Seminar Papers, 50-63. Atlanta: Scholars Press.

Hopkins, J 1989. Nieuwe Godsbeelden: Het experimernt van Sallie McFague. Wending: Tijdschrift voor Evangelie, Cultuur en Samenleving 44/4, 214-219.

Hopper, J 1987. Modern theology, I: Cultural revolutions and new worlds. Philadelphia: Fortress.

Kirsten, J M 1988. Die post-moderne projek: Aspekte van die hedendaagse afskeid van die moderne. Suid-Afrikaanse Tydskrif vir Wysbegeerte 7/1, 18-36.

Klemm, D E 1986. Introduction to Schleiermacher's The Christian faith, in Hermeneutical inquery, Vol II: The interpretation of existence, 7-12. Atlanta: Scholars Press. (AAR Studies in Religion 44.)

Kuhn, T S 1970. The structure of scientific revolutions. 2nd ed. Chicago: University of Chicago Press.

Lanser, S S 1981. The narrative act: Point of view in prose fiction. Princeton: University Press.

Malina, B 1986. Interpreting the Bible with anthropology: The case of the poor and the rich. Listening 21, 148-159.

Martin, J P 1987. Towards a post-critical paradigm. NTS 33, 370-385.

Oberholzer, J P 1989. Teologie as wetenskap: Aantekeninge van buite die sistematiese teologie. HTS 45, 438-441.

Pelser, G M M 1987. Die ontmitologiseringsprogram van Rudolf Bultmann. HTS 43, $162-191$.

Peters, T 1987. David Tracy: Theologian to an age of pluralism. Dialog 26, 298-305.

Ricoeur, P 1975. Biblical hermeneutics. Semeia 4, 29-145.

Sellin, G 1982. Allegorie und 'Gleichnis': Zur Formenlehre der synoptischen Gleichnisse, in Harnisch, W (Hrsg), Die neutestamentliche Gleichnisforschung im Horizont von Hermeneutik und Literaturwissenschaft, 367-429. Darmstadt: Wissenschaftliche Buchgesellschaft. (Wege der Forschung 575.)

Smuts, J C [1926] 1987. Holism and evolution. Cape Town: N \& S Press.

Tolmie, D F 1991. The function of focalisation in John 13-17. Neotestamentica 25, 273-288.

Tracy, D 1981. The analogical imagination. New York: Crossroad. 
Uspenski, B 1973. A poetics of composition: The structure of the artistic text and typology of a compositional form. Transl by V Zavarin \& S Wittig. Berkeley: University of California Press.

Van Aarde, A G [1980a]. 'n Nuwe benadering tot 'Gattungsforschung'. HTS 36/1 $\& 2,58-73$.

-.- [1980b]. 'Betekenis' en 'gebruik' in die makarismereeks (Mt 5:2-10). HTS 36/3 \& 4, 1-28.

--- [1981a]. Die kritiek op die fundamentalisme: 'n Vorm van teologiese liberalisme? HTS 37/4, 6-21.

-.- 1981b. Die Heilige Skrif - Woord en/of antwoord: Die Skrifbeskouing van James Barr. Die Hervormer Augustus 1981, bl 16.

-.- 1981c. Die Heilige Skrif - Woord en/of antwoord: Die Skrifbeskouing van James Barr. Die Henormer Oktober 1981, bl 16.

--- [1982a]. 'n Ondersoek na die Nuwe-Testamentiese makarisme en makarismereeks as 'Gattung'. HTS 38/1, 36-52.

-.- 1982b. Hoekom diversiteit in die Bybel? Die Henvormer Februarie 1982, bl 16.

--- 1982c. 'Tota Scriptura' en Bybelse Teologie. Die Henormer Maart 1982, bl 16.

--- 1982d. Matthew's portrayal of the disciples and the structure of Matthew 13:5317:27. Neotestamentica 16, 21-34.

... [1982e]. Die vertellersperspektief-analise: 'n Literatuurteoretiese benadering in die eksegese van die evangelies. HTS 38/4, 58-82.

-.- 1984. Die weg van die teks na die preek: Die verkondiging van die Nuwe Testament as 'n kommunikasie-gebeurtenis. HTS 40/1, 123-140.

.-. 1985a. Die outeurskapvraagstuk van die Johannesevangelie met die oog op interpretasie of resepsie. Sknf en Kerk 6/1, 43-62.

--- 1985b. Romeine 6:1-14 as 'n voorbeeld van 'n argumentatiewe teks met die oog op eksegese en prediking, in Smuts, A J (red), Die Woord aan die werk, 127-136. Pretoria: NG Kerkboekhandel.

-- 1985c. Die Skrif: Verdieping in die Reformatoriese grondstellings binne Hervormde teologie. Die Henormer April 1985, bl 16.

--- 1985d. Vertellersperspektief en die 'temporele funksie' van die Ou Testament in die Matteusevangelie. HTS 41, 272-289.

--- 1985e. Die gelykenisse van Jesus: Klassifikasie en prediking. HTS 41, 441-457.

-.. 1985f. Skrifgebruik: Hermeneutiese riglyne. HTS 41, 547-578.

-.. 1986a. Die wonderbaarlike vermeerdering van brood (Matt 14:13-21 en par): Die historiese kritiek in perspektief. HTS 42, 229-256. 
Van Aarde, A G 1986b. Plot as mediated through point of view: Mt 22:1-14 - A case study, in Petzer, J H \& Hartin, $\mathrm{P} \mathrm{J}$ (eds), A South African perspective on the New Testament: Essays by South African scholars presented to Bruce M Metzger during his visit to South Africa in 1985, 62-75. Leiden: Brill.

--- 1987a. Immanuel as die geïnkarneerde tora: Funksionele Jesusbenaminge in die Matteusevangelie as vertelling. HTS 43, 242-277.

--- 1987b. Gedagtes oor die begin van die kerk: 'n Geskiedenis van versoenende verskeidenheid. HTS 43, 325-351.

--- 1988a. Historical criticism and holism: Heading toward a new paradigm? in Mouton, J, Van Aarde, A G \& Vorster, W S (red), Paradigms and progress in theology, 49-64. Pretoria: HRSC.

--- 1988b. Narrative point of view: An ideological reading of Lk 12:35-48. Neotestamentica 22, 235-252.

..- 1988c. 1. Eksegetiese metodeleer: Die vertellersperspektief-analise, toegepas op die evangelies. 2. Inleiding tot die eksegese en teologie van die Johannesevangelie as verelling. Ongepubliseerde studiegids, Universiteit van Pretoria.

--- 1988d. Jesus en die sosiaal-veragtes. HTS 44, 829-846.

--- 1988e. Die Tessalonisense-korrespondensie. Ongepubliseerde studiegids, Universiteit van Pretoria.

--- 1989a. Die Eerste Brief aan die Tessalonisense, in Van Zyl, A H (red), Verklarende Bybel, 283-289. Kaapstad: Lux Verbi.

-. 1989b. Die Tweede Brief aan die Tessalonisense, in Van Zyl, A H (red), Verklarende Bybel, 290-293. Kaapstad: Lux Verbi.

--- 1989c. 'n Nuwe-Testamentiese begronding van die eenheid van die kerk en die eis om kerkeenheid vandag. HTS 45, 461-475.

--- 1989d. Handelinge 7:48 - 'Die Allerhoogste woon nie in mensgemaakte konstruksies nie'....: Die relevansie van die Nuwe-Testamentiese wetenskap na aanleiding van die metafoor 'tempel'. Professorale intreerede. Pretoria: Van Schaik. (Universiteit van Pretoria Nuwe Reeks 259.)

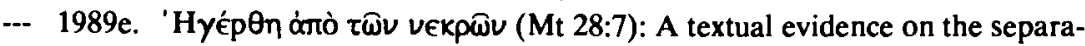
tion of Judaism and Christianity. Neotestamentica 23, 219-233.

--- 1989f. Resonance and reception: Interpreting Mt 17:24-27 in context. Scriptura 29, 1-12.

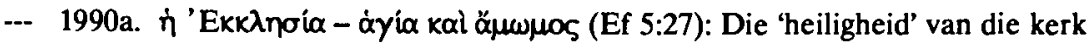
teen die agtergrond van die breuk kerk-sinagoge. In die Skriflig 24/3, 251-264.

--- 1990b. Die relevansie van die teologie vandag. Die Hervormer Januarie 1990, bl 9, 14. 
Van Aarde A G 1990c. Predikant is nie politieke leier, maatskaplike direkteur of volksleier nie. Die Henormer Maart 1990, bl 9, 14.

--- 1990d. Holisme as 'n postmodernistiese filosofie in teologiese lig. HTS 46, 293311.

--. 1991a. 'The Most High God does live in houses, but not houses built by men...': The relativity of the metaphor 'Temple' in Luke-Acts. Neotestamentica 25, 5164.

--- 1991b. Nuwe-Testamentiese teologie en metaforisiteit in teologiese teoretisering. Ongepubliseerde studiegids, Universiteit van Pretoria.

-.- 1991c. Hoe praat ons oor/van God? Teologiese idiome in die prediking. Voordrag gelewer by Hervormde Teologiese Vereniging, 26 Junie 1991.

--- 1991d. 'n Anti-Saddusese polemiek: 'n Nuwe suggestie in verband met die sosiale konteks van 2 Tessalonisense, in Roberts, J H, Vorster, W S, Vorster, J N \& Van der Watt, J G (reds), Teologie in konteks: Opgedra aan prof $A B$ du Toit, 344-375. Halfway House: Orion.

--- 1991e. 'n Nuwe-Testamentiese perspektief op die kind. HTS 47, 685-715.

--- 1991f. Natuurwonders, mens en omgewing (Matteus 17:24-27): Die wonderbaarlike vind van 'n silwermuntstuk in die bek van 'n vis, in Vos, C J A \& Müller, J C (reds), Mens en omgewing, 216-236. Halfway House: Orion.

--- [1992]. Organismic holism in the light of the modernity-postmodernity debate, in Mouton, J (ed), The relevance of theology for the 1990's. Pretoria: HSRC. (Forthcoming.)

Van Aarde, A G \& Van Eck, E 1989. Narratological analysis of Mark 12:1-12: The plot of the Gospel of Mark in a nutshell. HTS 45, 778-800.

Van Arkel, J G de J 1988. Theology beyond Newton: A quantum leap, in Mouton, J, Van Aarde, A G \& Vorster, W S (eds), Paradigms and progress in theology, 223-238. Pretoria: HRSC.

Van der Merwe, P J 1989. Paradigmas en progressie in die teologie: 'n Perspektief op die RGN-kongres van April 1988. HTS 45, 476-507.

Van Eck, E 1986. Die funksie van ruimte in die narratologie. HTS 42, 139-149.

-- 1990. Die ideologiese funksie van tyd en ruimte in die vertelkunde toegepas op die Markusvertelhng. MA-verhandeling, Universiteit van Pretoria.

--. 1991. 'n Sosiaal-wetenskaplike ondersoek na die 'amp' van die ouderling in die Nuwe Testament. HTS 47, 635-655.

Van Staden, P 1990. Compassion - the essence of life: A social-scientific study of the symbolic universe reflected in the ideology/theology of Luke. DD-proefskrif, Universiteit van Pretoria. 
Venter, M A 1989. Schleiermacher in perspektief. BD-skripsie, Universiteit van Pretoria.

Vorster, W S 1987. Op weg na 'n post-kritiese Nuwe-Testamentiese wetenskap. HTS 43, 374-394. 